\title{
Conservation status and natural history of Ctenomys, tuco-tucos in Bolivia
}

\author{
Scott L. Gardner ${ }^{1 *}$, Sebastian Botero-Cañola ${ }^{1}$, Enzo Aliaga-Rossel ${ }^{2}$, Altangerel Tsogtsaikhan Dursahinhan ${ }^{1}$, and Jorge Salazar-Bravo³ \\ ${ }^{1}$ Manter Laboratory of Parasitology, University of Nebraska State Museum, and School of Biological Sciences, University of Nebraska- \\ Lincoln, Lincoln, Nebraska, USA 68588-0514. Email: slg@unl.edu (SLG), seboca18@gmail.com (SB-C) stylodipusats@gmail.com (ATD). \\ ${ }^{2}$ Colección Boliviana de Fauna, Instituto de Ecologia, Universidad Mayor de San Andrés, Cota Cota Calle 27, Campus Universitario, \\ La Paz, Bolivia. Email: ealiagar@hotmail.com (EA-R). \\ ${ }^{3}$ Department of Biology, Texas Tech University, Lubbock, Texas, U.S.A. Email: j.salazar-bravo@ttu.edu (JS-B). \\ ${ }^{*}$ Corresponding author
}

The genus Ctenomys consists of about 70 species and in addition to the Geomyidae of the Nearctic, Neotropical tuco-tucos represent a weII-documented case of diversification in the subterranean biotype. Here we will: i) Provide an updated summary of the natural history of the 12 species of extant tuco-tucos from Bolivia; ii) Update information on distributions of each species; and iii) Using ecological niche modeling, evaluate recent and projected habitat transformation or habitat degradation within the known range of each species to provide a preliminary assessment of the preservation or conservation status of ctenomyids within Bolivia. We follow Gardner et al. (2014) and combine species summaries with both updated published and new data to compile a complete list of known extant species of tuco-tucos from Bolivia. Occurrence data for Ctenomys in Bolivia and surrounding areas were extracted from the database Arctos and GBIF. All individual specimen-based locality records were checked and georeferenced by referring to original museum collection records. We created species distribution models for the species with enough locality records using climate and soil data, while for the rest of the species we estimated the ranges based on the known occurrence localities. Finally, we quantified the amount of large-scale habitat conversion occurring within each species range, as well as the potential effect of climatic change on species distribution. Here we present information regarding the biology of tuco-tuco (Ctenomys) species known to occur in Bolivia, including unpublished natural history data such as habitat association, interactions and activity patterns gathered by the authors through extensive field work. Besides this, we estimated the current distribution of Ctenomys species, quantified large-scale habitat transformation within each species range and assessed the potential effect of climatic change on five tuco-tuco species. We found that the habitats within the ranges of $C$. boliviensis and C. steinbachi have experienced significant land-cover conversions in recent years. We also show that $C$. opimus, as well as the above mentioned species are expected to undergo range contractions resulting from climatic change by 2070. Our review shows that there is a dearth of information regarding natural history, taxonomy and distribution for many Bolivian tuco-tuco species. Nonetheless, the information presented here can be a tool for directing and focusing field studies of these species. This is of great importance if we take into account that most of the Bolivian tuco-tucos are subject to one or several conservation/preservation threats. These include: Habitat destruction via land use or climatic changes in conjunction with geographic ranges of Ctenomys that are small in areal extent and which in many cases are not adequately covered by protected areas.

El género Ctenomys cuenta con alrededor de 70 especies. Al igual que la familia Geomyidae en el Neártico, los tuco-tucos representan un claro caso de diversificación adaptativa al biotipo subterráneo en el Neotrópico. En este trabajo presentamos: i) una síntesis de la historia natural de las 12 especies actuales de Ctenomys registradas en Bolivia; ii) información actualizada de su distribución; y iii) una evaluación de la degradación del hábitat dentro del rango de cada especie con el fin de brindar una evaluación preliminar del estado de conservación de los tuco-tucos de Bolivia. A partir del trabajo de Gardner et al. (2014), información publicada y nuevos datos, compilamos una lista completa de las especies de tuco-tucos (Ctenomys) de Bolivia junto con la información disponible sobre su biología e historia natural. Las localidades de ocurrencia de las especies en Bolivia fueron obtenidas de las bases de datos GBIF y Arctos. Toda la información sobre las localidades de ocurrencia fue posteriormente depurada y georreferenciada, haciendo referencia a los registros originales de las colecciones de museos. Adicionalmente, creamos modelos de distribución para las especies con suficientes registros. Para las especies menos colectadas, estimamos la distribución a partir de las localidades de ocurrencia e información sobre su hábitat. Finalmente, cuantificamos la transformación del hábitat ocurrida dentro de los rangos de cada especie, al igual que el efecto potencial del cambio climático sobre su distribución. Presentamos un resumen del conocimiento de la biología de cada una de las especies que ocurren en Bolivia, incluyendo datos no publicados de historia natural colectados por los autores durante varias décadas de trabajo de campo. Entre estos nuevos aporte se encuentran descripciones de hábitat, interacciones y patrones de actividad. Adicionalmente, presentamos estimaciones de la distribución, cuantificamos la conversión a gran escala del hábitat y evaluamos el efecto potencial del cambio climático sobre las especies de tuco-tucos en Bolivia. Encontramos que los rangos de distribución de C. boliviensis y C. steinbachi han experimentado importantes cambios en las coberturas vegetales naturales y seminaturales en años recientes. Adicionalmente proyectamos que la distribución de estas dos especies, junto con la de C. opimus experimentarán contracciones importantes como consecuencia del cambio climático para el año 2070 . La información revisada en este trabajo muestra que hay importantes vacíos de conocimiento con respecto a la historia natural, taxonomía y distribución en la mayoría de especies de tuco-tucos de Bolivia. Sin embargo, la información presentada en este trabajo puede servir como herramienta para guiar trabajos de campo sobre estas especies. Esto es de gran importancia si se tiene en cuenta que la mayoría de las especies de Ctenomys que ocurren en Bolivia presentan uno o varios factores que amenazan su conservación, como la pérdida de hábitat por transformaciones de las coberturas, el cambio climático, y los rangos de distribución pequeños y con mínima representación en áreas protegidas.

Keywords: Bolivia; Caviomorpha; climate change; Ctenomyidae; Ctenomys; Hystricomorpha; land use change; natural history; species distribution model; subterranean rodents. 


\section{Introduction}

Rodents are the most speciose of all orders of mammals, having a cosmopolitan distribution with extant autochthonous species on all continents except Antarctica (Wilson and Reeder 2005). At the current time, even though new species of mammals are being described at a fairly high rate globally, many forms remain unknown and undescribed and the natural history of most known species is still obscure (Wilson et al. 2017). Over time, the subterranean niche has been repeatedly invaded by species from several independent lineages of rodents in disparate geographic areas (Lacey and Patton 2000) leading in many cases to extensive diversification and speciation with examples especially salient in species comprising the Geomyidae in the Nearctic and northern Neotropical regions, the Bathygeridae in the Ethiopian region, Spalacidae in the Palearctic region, and the Ctenomyidae in the southern neotropics (Lacey et al. 2000; Wallace 1876; Wilson et al. 2017).

One of the most diverse and speciose groups of subterranean rodents includes members of the genus Ctenomys Blainville, 1826 (Ctenomyidae). Species of Ctenomys occur in suitable habitats in South America with a known northernmost limit of distribution of around $12^{\circ} \mathrm{S}$. latitude in western Brazil and about $14^{\circ} \mathrm{S}$ just to the west of Lake Titicaca on the Altiplano of Peru. Many other species occur south in Bolivia, Paraguay, Uruguay, Argentina, and Chile, even extending south to the island of the Tierra del Fuego (Wilson et al. 2017). The genus Ctenomys now includes an estimated 70 species and in addition to species in the Geomyidae that occur mostly in the Nearctic, the tuco-tucos represent a well-documented case of diversification in the subterranean biotype (Teta and D'Elia 2020; Gardner et al. 2014; Bidau 2015; Wilson et al. 2017).

The species in the genus Ctenomys are broadly known through their distributional range as tuco-tucos because of the vocalizations made by individuals in their burrows that are detectable by persons listening above ground (Darwin 1860). Field surveys have made it clear that the true species diversity in Ctenomys is unknown due to the cryptic nature of these rodents and the fact that many geographic areas that may support populations of tuco-tucos in the Neotropics have not yet been adequately surveyed (Gardner et al. 2014).

Tuco-tucos range in size from small to medium-sized rodents (Figure $1 \mathrm{~A}$ ) with a morphologically fusiform and compact body shape, loose skin that allows them to easily turn in a burrow, short legs, and long claws on their forefeet for tunneling. On their forefeet they have relatively thick, rapidly-growing nails that they use to dig their tunnels. On their rear feet, they have strong nails and they have welldeveloped ctenidia or combs (Figure 1 B) on the margins of their pes, and these hard bristle-like combs (kteis = comb in Greek - mys = mouse in Greek; thus the name comb-footedmouse $=$ (tenomys) assist the animal in kicking soil out of the burrow. In contrast to species of Geomyoidea that have a behavior in which all species that have been observed, push soil through and out of their burrows with their front feet (Eisenberg 1962), all species of Ctenomyidae studied up to the current time push and kick the soil through and from their burrows using only their rear feet (S.L. Gardner, pers. obs). As far as is known, this rear-soil-kicking action appears to be a behavioral trait that is plesiomorphic in the ctenomyids and may be a behavioral synapomorphy when also considering the Octodontidae which contains the species considered as the sister group of the Ctenomyidae. Ctenomyids have large heads, small pinnae, and relatively well-haired but tactile tails. Variability in color of the pelage, even within populations, coupled with high levels of variation in both diploid and fundamental numbers of chromosomes in some species set the stage for the current state of affairs in the taxonomy of species in this genus where a relatively large number of species names are available (Gardner et al. 2014).

Although there are studies of their biogeography, phylogeny, evolution, taxonomy, ecology, sociality, and parasitology (e.g. Gardner 1991; Cook and Yates 1994; Lessa and Cook 1998; Cook and Lessa 1998; Mascheretti et al. 2000; Castillo et al. 2005; Freitas 2006; Parada et al. 2011; Gardner et al. 2014), basic information available on ecological aspects, local and regional distributions, biology, and reproduction are still relatively scarce, especially in Bolivia, a country with great, and probably underestimated, tucotuco species diversity. The great potential for discovery of new species and the concomitant need for research on all aspects of the biology of Ctenomys in Bolivia is exemplified by the description of four new species from collection efforts, initially started by Dr. Sydney Anderson, that took place from about 1984 up to the current time over many areas of the country (Anderson 1997; Gardner et al. 2014). Also, the restricted distribution of the known endemic species of Ctenomys in Bolivia, coupled with the rapid largescale land use changes consisting mostly of industrial agriculture that is being established throughout the eastern lowlands of the country suggests the importance of the ctenomyids from a species conservation/preservation perspective (Caraballo et al. 2020). Furthermore, of the 12 tuco-tuco species documented to occur in Bolivia, little is known of their population structure, numerical density, and conservation status; and of these, only seven species have been formally evaluated by the IUCN (IUCN 2020).

In Bolivia, the 12 species of tuco-tucos, cujuchis (cuhuchi), topos, or tojos (Anderson 1997) that are known to occur there are distributed through the southern half of the country ranging from a westernmost distribution on the Altiplano near Lake Titicaca south through the Altiplano. They also occur through the Andes east into the Yungas through the lowland regions of eastern Bolivia. At least 3 of the known species each have scientific reports from only one collection locality. In Bolivia, besides basic data on species descriptions and a few spurious records (Anderson 1997; Gardner et al. 2014) there is little additional information available in the literature on these rodents. This paper reviews and summarizes published literature, museum 
records, and unpublished data from extensive field work by (SLG and JSB) in the country with several objectives. Here we will: i) Provide an updated account of the natural history of extant tuco-tucos from Bolivia; ii) Update information on species distributions in Bolivia; and iii) Assess recent and projected habitat transformation or habitat degradation within the known range of each species to provide a preliminary assessment of the preservation or conservation status of ctenomyids within Bolivia.

\section{Materials and Methods}

We follow the general systematic summary and taxonomy of Gardner et al. (2104) and we used the species descriptions found therein to compile a complete list of known extant species of tuco-tucos from Bolivia. To report general sizes of body (in millimeters), we used data directly from Gardner et al. (2104) and from unpublished data taken by SLG from museum specimen tags, weight is reported in grams. Number of individuals is given followed by the mean of the measurements.

To update occurrence data for Ctenomys in Bolivia, we used verified collection records from the Arctos database and the Global Biodiversity Information Facility (GBIF). We georeferenced and checked each individual specimenbased locality record by referring to original museum collection records. This double-checking was necessary because we discovered a significant number of errors in the GBIF data-set. These errors were traced primarily to improper reciprocal translation of the format of degree-minute-second to the format of decimal degrees by either automatic computer assisted operations or human error. We include the updated/corrected database as supplementary material. For the summary account for each species of tucotucos, citations of the literature describing relevant characters and other data are given at the beginning. Means are given for all measurement data. Colors regarding these animals generally follow Gardner et al. (2104) and these color definitions are all derived from Ridgeway (1912).

Species distribution estimation. To provide estimates of the distribution of species of Ctenomys in Bolivia, we created species distribution models (SDMs) for the taxa that have sufficient numbers of verified occurrence or collection records. Although SDM's are widely used in studies of biogeography and conservation biology and their predictive power and utility have been repeatedly shown (Phillips and Dudík 2008; Raxworthy et al. 2003), there are some factors that could introduce bias in the models and affect both robustness and predictive performance. Probably, the most important of these factors is that records of the presence of animals at a locality usually do not come from a random sampling of the study area and sometimes the data might be spatially clumped, due to any number of logistical reasons for collecting in one locality, resulting in models biased in some way, which in the worst cases are predicting sampling conditions rather than suitability for the studied species (Fourcade et al. 2014). However; when our team collects tuco-tucos, we go where they exist, and because of the burrow systems and soil that is thrown up at the mouth of each tunnel, it is relatively easy to see where these mammals are (and where they are not) over geographic space. In many cases, for the Ctenomys species in question, the absence of collection records means that no (or few) individuals exist in these areas. The potential missing information derives from the fact that we only collected tuco-tucos where roads existed at the time of our surveys in Bolivia. Finally, most of the collection localities cited in this paper are given in Anderson (1997) and Gardner et al. (2104. The other potential problem is the risk of creating very complex models overfitting the training data, but with little predictive or extrapolation power (Muscarella et al. 2014). Finally, when no true absence data are available, it is very important that the study area from which background environmental data is extracted, is in fact the area accessible to the species over relevant time periods (Barve et al. 2011).

In order to account for the above factors, we took the following modeling approach; first, we defined the study area for each species as the minimum convex polygon of all the recovered specimen collection records, plus an 80 $\mathrm{km}$ buffer, a value selected taking into account the potentially limited dispersal capability of these subterranean rodents; however, as pointed out by Busch et al. (2000) little work has been done on the ecology of dispersal in subterranean rodents and essentially none has been conducted in Bolivia. Second, we reduced spatial sampling bias by removing one of each pair of records that were closer than $5 \mathrm{~km}$ from each other using the R package SPTHIN (AielloLammens et al. 2015), thus using only what we assume to be spatially independent records. Given that many of the Bolivian species of Ctenomys have few spatially independent sampling records (6 to 31), we employed the approach proposed by Breiner et al. (2015), of creating ensembles of small models (ESM) using the $\mathrm{R}$ package ecospat (Di Cola et al. 2017), in which models were developed for each pair of environmental prediction variables and using different algorithms, and a final consensus model created by averaging predicted suitability weighted by each simple model performance. With this approach, overfitting is reduced as the number of parameters in each model is small relative to the number of occurrences and has been shown to perform well for species with scarce presence data. Here, we created models employing all variable combinations and employing Maxent and GBM (gradient boosting machine) algorithms, as these were found to provide the most robust models which are transferable and the highest predictive performance respectively in an empirical evaluation of ESM (Breiner et al. 2018). Subsequently, we assessed the significance of each ensemble model using the area under the partial ROC, above an omission threshold of $10 \%$ as implemented in the R package kuenm (Cobos et al. 2019). Finally, we estimated the distribution of suitable habitat by reclassifying the continuous suitability map to presence-absence using the threshold that retains $98 \%$ of the species records. 
This threshold was selected to predict all records of the species with low sample sizes and provide an inclusive estimation of suitable habitat.

To model habitat suitability, we used 15 bioclimatic variables that were obtained from WorldClim 2.0, which provides precipitation and temperature averages and variability (Fick et al. 2017). We did not include the bios variables $8,9,18$, and 19 as they might show correlation artifacts resulting from their dependence on both precipitation and temperature (Campbell et al. 2015). Besides climatic information, and taking into account the subterranean lifehabits of Ctenomys, we employed five variables describing soil properties, including: Bulk soil density, sand content, clay content, organic material content, and silt composition at a level of $15 \mathrm{~cm}$ below the surface - these soil data were derived from a set that was predicted at a global scale by Hengl et al. (2017). For our analysis, we reduced the number of variables and avoided including highly correlated ones by performing a principal component analysis (PCA) on separate climate and soil raster datasets. Of these resulting uncorrelated, orthogonal components generated by PCA, we used the first 6 PCs that in fact explained $99 \%$ of the variation in climate. Relative to soil properties, we chose the first 4 components that actually accounted for $100 \%$ of this variation. Finally, we evaluated the average importance of each of the types of data to assess the utility of soil properties to model species distributions of these subterranean mammals. To enhance reproducibility of these SDM, we use the ODMAP (Overview, Data, Model, Assessment and Prediction) protocol to provide a detailed report of our modelling process and data sources (Zurell et al. 2020).

For the species with insufficient independent collection locality records available that would enable us to create a robust model of their distribution using habitat variables, we provide minimum-distribution polygons derived from museum-based occurrence records, field work experience, field notes, and information on habitat associations. For species with only one locality record, we follow Caraballo et al. (2020) in which we assume the distribution area to be a circular buffer with a $38 \mathrm{~km}$ radius although we realize that true locality-occurrence of these mammals depends completely on the soil characteristics in and around the collection locality.

Recent and future habitat change. We assessed the potential effect of two important threats to the diversity of Bolivian tuco-tucos, including: (1) anthropogenic habitat conversion from natural/seminatural to agricultural and urban systems, and (2) global warming and associated climate change. To assess the magnitude of anthropogenic land cover change within the range of each species, we employed the land cover classification of the Copernicus Climate Change Service for 1993 and 2018 (https://cds. climate.copernicus.eu/cdsapp\#!/dataset/satellite-landcover?tab=overview). Given that detailed data on habitat use and anthropogenic tolerance is lacking for most of the tuco-tuco species, our aim was to quantify large scale transformation coinciding with the ranges of each species of
Ctenomys considered here. To do this, we classified urban, rainfed and irrigated/post flooding agriculture categories from original classification as anthropogenic intensive land covers; and the reminder land cover types as natural/ semi natural which beside natural covers included mosaics of cropland and natural vegetation and pastures. We included these categories as semi-natural because at least some species can survive in these habitats (e.g. C. boliviensis and C. erikacuellarae, see Gardner et al. 2014). In this way, we obtained a conservative estimate of large scale changes within the geographic range of the species of interest. We report the net percentage of natural/semi natural habitat within each species range in the year 2018, as well as the percentage of habitat loss between the years, 1993 to 2018 as a measure of more recent and/or ongoing loss of habitat.

To estimate the change in suitable habitat resulting from global warming we projected the distribution models into the climatic projections for 2070 from the 17 general circulation models (GCM) available at the WorldClim database under the contrasting 4.5 and 8.5 emission scenarios (RCPs) from the 5th Assessment Report of the United Nations Intergovernmental Panel on Climate Change (IPCC). The first scenario corresponds with a peak in emissions around 2040 and further emissions decline with stabilization around 2100; the second, more pessimistic scenario presents emissions rising throughout the 21st century (http://www.ipcc. $\mathrm{ch} /$ ). We estimated suitability for each GCM RCP combination and predicted gain and loss of suitable habitat specifically for the ctenomyids of Bolivia for the median suitability of each scenario using the same threshold used in the current distribution model. We used the same soil variables.

\section{Results}

Species summaries -Ctenomys of bolivia:

\section{Ctenomys opimus Wagner, 1848}

(Figure 2, A, B, C, D; Map Figure 9)

Common name: highland tuco-tuco, tuco-tuco Andino.

Morphology: $(n=56)$ Body length 284; tail 83; hindfoot 42; ear 9; weight 306. When adults, these tuco-tucos are relatively large with a pale yellowish color. In some localities, individuals have darker fur with black intermixed with the pale yellow. Older individuals may have worn hair on top of the head, probably from moving through the burrow system and digging. Pelage is long and soft. The auditory canals are relatively short, associated with large auditory bullae. The upper incisors are slightly procumbent and the enamel on the teeth is orange in color. Gardner and Anderson (2001) noted that C. opimus has curious holes in the cranium, usually between the frontal and parietal bones and can be relatively common with $80 \%$ of highland tuco-tucos in Bolivia showing this character. A great summary of the morphology of this species is given in Cook et al. (1990).

Distribution: Ctenomys opimus has a wide distribution with a documented geographic range from south- 
ern Peru (southwest of Lake Titicaca - see map, Figure 9) south through northeast Chile, the Altiplano of Bolivia, into extreme northwestern Argentina. In Bolivia, the highland tuco-tuco is found in the high-Andean puna habitat of the departments of La Paz, Oruro, and Potosi. The SDM (Table 1) we generated for this species predicts $100,733 \mathrm{~km}^{2}$ of suitable habitat through the Altiplano except for the inhospitable Salar de Uyuni.

Natural history: Pearson (1959) studied C. opimus in southern Peru and provided some of the earliest detailed observations of the natural history of tuco-tucos. Anderson (1997) recorded that pregnant females were trapped in August, October, and December similar to observations made by Pearson in Peru, numbers of embryos ranged from 1 to 5 (mean 2.8), with a gestation period of approximately two months (Pearson 1959). Non-pregnant females were also recorded in August and September with a higher proportion of births evidently occurring from October through March each year (Anderson 1997).

From Puna habitat at 3,950 m., $7 \mathrm{~km} \mathrm{~S}$ and $4 \mathrm{~km} \mathrm{E}$, Cruce Ventilla $\left(19^{\circ} 08^{\prime} \mathrm{S} ;-66^{\circ} 07^{\prime} \mathrm{W}\right)$, a locality that our expedition visited on 30 September, 1986, we observed that individuals of C. opimus inhabited burrow systems that were also used by at least two other species of rodents. Collected from the same burrow systems (the specimens came out of the same burrow mouth and all were collected by SLG by shooting) were individuals of $C$. opimus, Phyllotis xanthopygus (Waterhouse, 1837), and Galea musteloides Meyen, 1832. During the time we spent at this site, we observed that the burrow systems of the tuco-tucos were not closed with more than about $5 \mathrm{~cm}$ of soil. Usually (for all individual burrow systems that we have studied throughout Bolivia) the entrance to the burrow of the tuco-tuco is almost always plugged with soil for more than $10 \mathrm{~cm}$ (sometimes much more), unless the animal is actively plugging the burrow mouth and was interrupted before it was finished with its work. At this site, during the day, these three species of rodents emerged from the same burrow systems at irregular intervals, sometimes with dozens of $P$. xanthopygus coming out of the burrow systems simultaneously, while at the same time G. musteloides and C. opimus were emerging. The individuals of $C$. opimus that were observed always stayed partially in their burrow, never leaving it completely, while the two other species of rodents strayed meters from the various mouths of the burrow systems. Individuals of all three species were collected easily with a shotgun at this site. Interestingly, when our expedition again visited the site in 1990, there remained no evidence of these rodents, the tuco-tuco colony evidently either suffering a local extinction or the colony and associated inquilines having moved on through the landscape (Gardner pers obs. 1993). Parasites - Studies of the parasites of C. opimus have yielded the description of four new species of Eimeria (Coccidia: Apicomplexa) including: Eimeria opimi, E. oruroensis, E. granifera, and E. montuosi (authority names all Lambert et al. 1988). Specific localities for these protistan parasites are given in Lambert et al. (1988) and Gardner and Duszynski (1990). In addition, two species of nematodes, Litomosoides andersoni and L. ctenomyos Brant and Gardner (1997) (Nemata: Filaroidea) were discovered and described from tuco-tucos at the Huancaroma locality (Oruro: Rancho Huancaroma, $17^{\circ} 40^{\prime} \mathrm{S} ;-67^{\circ} \quad 27^{\prime} \mathrm{W}, 3,720$ $\mathrm{m}$. altitude). Other nematodes collected at this locality included Paraspidodera (Nemata: Heterakoidea) and Trichuris (Nemata: Trichurata) both in very high prevalence and intensity of infection. In addition, from 32 highland tucotucos collected from the Huancaroma locality $\left(17^{\circ} 40^{\prime} \mathrm{S}\right.$; $-67^{\circ} 27^{\prime} \mathrm{W}$ ) by members of our expedition in 1986 , a single individual that was examined harbored one specimen of a large form of Mathevotaenia (Cestoda: Anoplocephalidae) which is now being described as a new species. Ectoparasites identified from our collecting throughout the range of C. opimus in Bolivia included fleas Ectinorus galeanus Jordan, 1939 (Siphonaptera: Rhopalopsyllidae) from the same Huancaroma locality listed above, chewing lice (Phtheiropoios sp.) currently being described as new, and beetles of the family Staphylinidae (Edrabius weiseri Seevers 1955). In addition, beetles of this species were reported from C. opimus from other localities in Bolivia including $7 \mathrm{~km}$ south, $4 \mathrm{~km}$ east, Cruce Ventilla, Dept. Potosi and $2 \mathrm{~km}$ east, ENDE camp, northeast shore of Laguna Colorado, 4,280 m. (Ashe et al. 1996).

The community of rodents at the collection locality near Cruce Ventilla was also interesting in that the only parasites that were shared among these rodents that lived in the same burrow systems were cestode larvae we discovered in

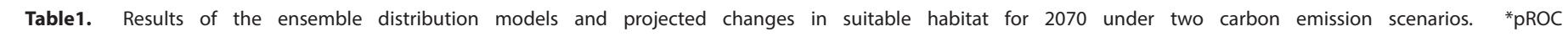
ratio significantly different from 1 , meaning that the model is statistically significant.

\begin{tabular}{|c|c|c|c|c|c|c|c|c|c|c|}
\hline Species & $\mathbf{N}$ & Study area & $\begin{array}{l}\text { Predicted suit- } \\
\text { able Area }\left(\mathbf{k m}^{2}\right)\end{array}$ & $\begin{array}{c}\text { Predicted suitable } \\
\text { Area Bolivia Area } \\
\qquad\left(\mathbf{k m}^{2}\right)\end{array}$ & $\begin{array}{l}\text { pROC } \\
\text { ratio }\end{array}$ & AUC & $\begin{array}{l}\text { Bioclimatic } \\
\text { variables } \\
\text { contribution }\end{array}$ & $\begin{array}{l}\text { Soil variables } \\
\text { contribution }\end{array}$ & $\begin{array}{c}\text { \%Suitable } \\
\text { habitat change } \\
\text { RCP4.5 }\end{array}$ & $\begin{array}{c}\text { \%Suitable } \\
\text { habitat change } \\
\text { RCP4.5 }\end{array}$ \\
\hline Ctenomys opimus & 31 & 445,644 & 187,163 & 107,733 & $1.6^{*}$ & 0.84 & 0.1 & 0.09 & $-34 \%$ & $-22 \%$ \\
\hline Ctenomys steinbachi & 8 & 44,770 & 2,690 & 2,690 & $2^{*}$ & 0.86 & 0.11 & 0.09 & $-61 \%$ & $-58 \%$ \\
\hline Ctenomys frater & 17 & 210,035 & 104,383 & 34,443 & $1.5^{*}$ & 0.71 & 0.09 & 0.12 & $-8 \%$ & $-9 \%$ \\
\hline Ctenomys boliviensis & 25 & 97,941 & 14,347 & 14,347 & $1.8^{*}$ & 0.88 & 0.12 & 0.07 & $-78 \%$ & $-26 \%$ \\
\hline Ctenomys conoveri & 15 & 202,966 & 62,437 & 28,936 & $1.7^{*}$ & 0.77 & 0.09 & 0.11 & $+12 \%$ & $+34 \%$ \\
\hline
\end{tabular}


the mesenteries of the rodents. These were metacestodes of the genus Taenia and were identified by R. L. Rausch and SLG in 1988 (pers. obs.) as Taenia talicei Dollfus, 1960 which were multi-strobilate larval forms. Another paper describing these associations is in preparation.

Species Conservation/Preservation Status: Ctenomys opimus is globally categorized as a species of least concern (LC) by the IUCN (Dunnum et al. 2016) and is not mentioned in the Libro Rojo de la Fauna Silvestre de Vertebrados de Bolivia (Ministerio de Medio Ambiente y Agua 2009; LRVSB). The suitable conditions for this species are expected to contract by $34 \%$ and $21 \%$ under the GCM 4.5 and GCM 8.5 respectively, indicating that climatic change will have an important impact over this species (Figure 11; Table 1). Most of the estimated distribution of the species comprises natural, seminatural, and grassland/pastures vegetation covers (Table 2 ). Through the geographic area occupied by this species, around $21 \%$ of its range is under protection. In Bolivia protected areas include: Reserva Natural y Deportiva Cerro Viscachchani, Refugio de Vida Silvestre Huancaroma, Parque Nacional Sajama, Reserva de Fauna Eduardo Avaroa, Parque Nacional Yura, and Patrimonio Nacional y Reserva Ecologica Poopo (Caraballo et al. 2020).

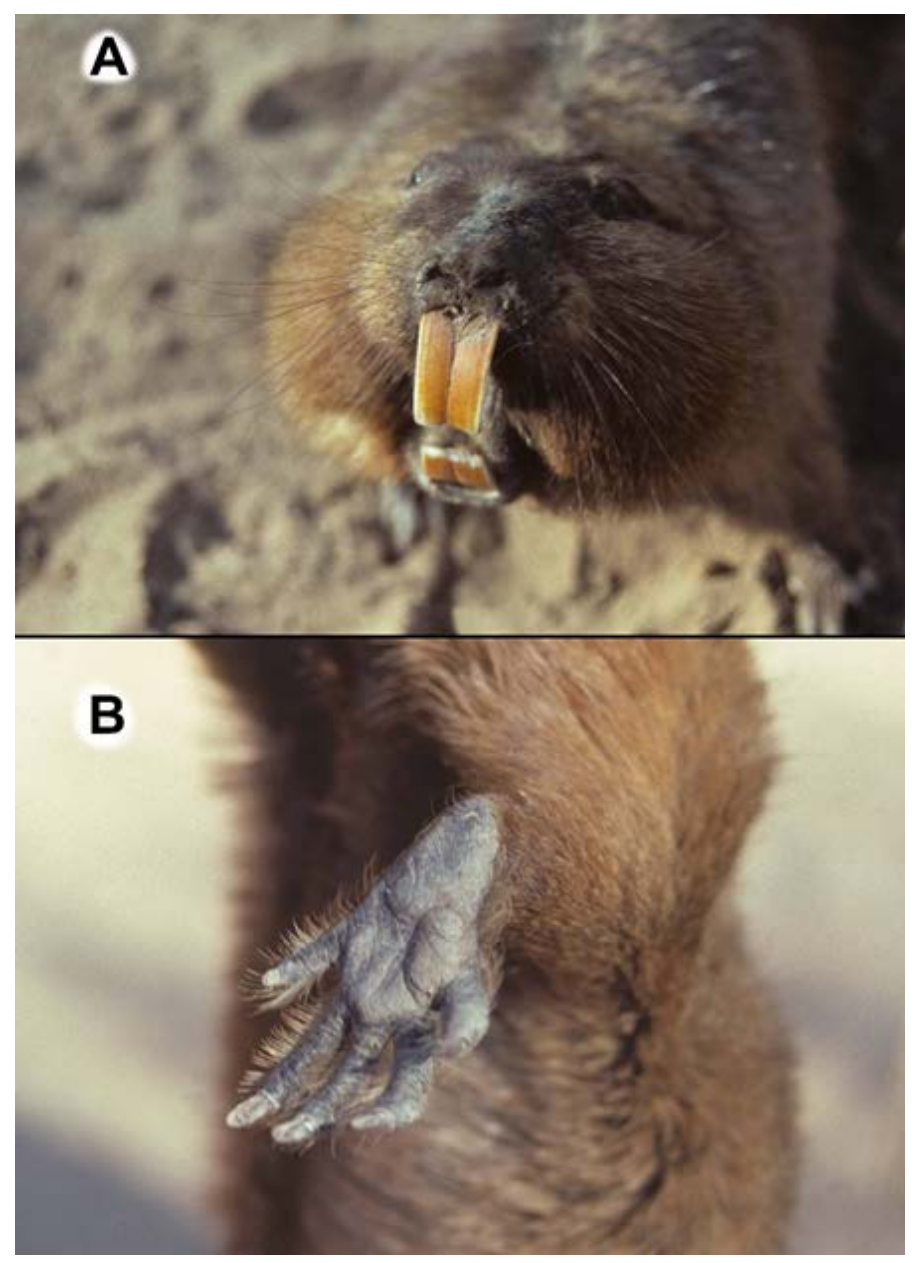

Figure 1. A. Ctenomys conoveri showing Orange, slightly grooved incisors. B. Left rear pes and claws of Ctenomys conoveri showing comb-like bristles on the margins of the toes.
Ctenomys andersoni Gardner et al. 2014

(Figure 2 A, B, C; Map, Figure 9).

This species was named by Gardner and colleagues in honor of Dr. Sydney Anderson. Syd was a major catalyst for the continuing work on the mammals of Bolivia and his encouragement and teaching to both students and professionals has had profound effects on the overall understanding of the biodiversity of Bolivia. His work in Bolivia, starting in 1964 accelerated through and beyond the completion of his monograph: "Mammals of Bolivia: Taxonomy and Distribution" in 1997 (Anderson 1997).

Common name: Anderson's tuco-tuco, Anderson's cujuchi.

Morphology: From the original description of C. andersoni by Gardner et al. (2014) ( $\mathrm{n}=27$ ) Body length 253; tail 69.8; hindfoot 33.8; ear 6.8; weight 219.9. Ctenomys andersoni is a medium-sized tuco-tuco with brown dorsal coloration, an indistinct dorsal Olive Brown stripe, and no cap of dark hairs on its head (Figure $2 \mathrm{G}$ ). The ventral fur is much lighter and is well-differentiated from the dorsum. In contrast to many other species of ctenomyids, there is no obvious collar of differently colored fur in the gular region but there is a small patch of slightly lighter fur extending ventrad around and just below the pinnae. The most distinctive features of the skull and mandible of $C$. andersoni are the brightly colored Orange incisors (Figure $2 \mathrm{E}, \mathrm{F}$ ). For a complete description of the cranium of this species, see Gardner et al. (2014).

Distribution: The type locality and only geographic location from where specimens of $C$. andersoni have been collected is Cerro Itahuaticua in the department of Santa Cruz at an elevation of $810 \mathrm{~m}\left(19^{\circ} 48^{\prime} \mathrm{S} ;-63^{\circ} 31^{\prime} \mathrm{W}\right.$; Figure 9$)$. No SDM was constructed for this species since there are not enough occurrence data points (specimens collected more than a few $\mathrm{km}$ apart) to enable this type of analysis.

Natural history: The habitat at the collection locality of C. andersoni comprises one area in the Andean dry valleys zone with a mixed vegetation of deciduous thorny trees and cacti as well as limestone outcrops on the hillsides. No other data are available on the ecological characteristics of the habitat of this species. The only other species of cajuchi that occurs in the general area from which C. andersoni was discovered are C. erikacuellarae Gardner et al. 2014 to the west (about 50 straightline $\mathrm{km}$ ) and C. conoveri Osgood 1946 to the southeast (about 100 straightline $\mathrm{km}$ ) see map in Figure $8 \mathrm{C}, \mathrm{D}$ ). Parasites - Chewing lice (Phtheiropoios sp.) and nematodes of the genus Paraspidodera were collected from the type series of these mammals and these are being described as new species. New records of fleas have been reported (see Pucu et al. 2014 or a list).

Conservation/Preservation Status: The biological status relative to numerical density and viability of the populations of this species has not yet been evaluated by the IUCN. Little large-scale habitat conversion has occurred around the area where this tuco-tuco was collected $(<1 \%)$ and $96 \%$ of the habitat is under natural or semi-natural con- 
ditions (Table 2). However, because $C$. andersoni is known only from a very restricted geographic range at the type locality and only $3 \%$ of the area near the type locality lies within the municipal protected area of Serrania SararendaCuervo (Caraballo et al. 2020), we consider this species as susceptible and vulnerable to immediate extirpation by anthropogenic causes.

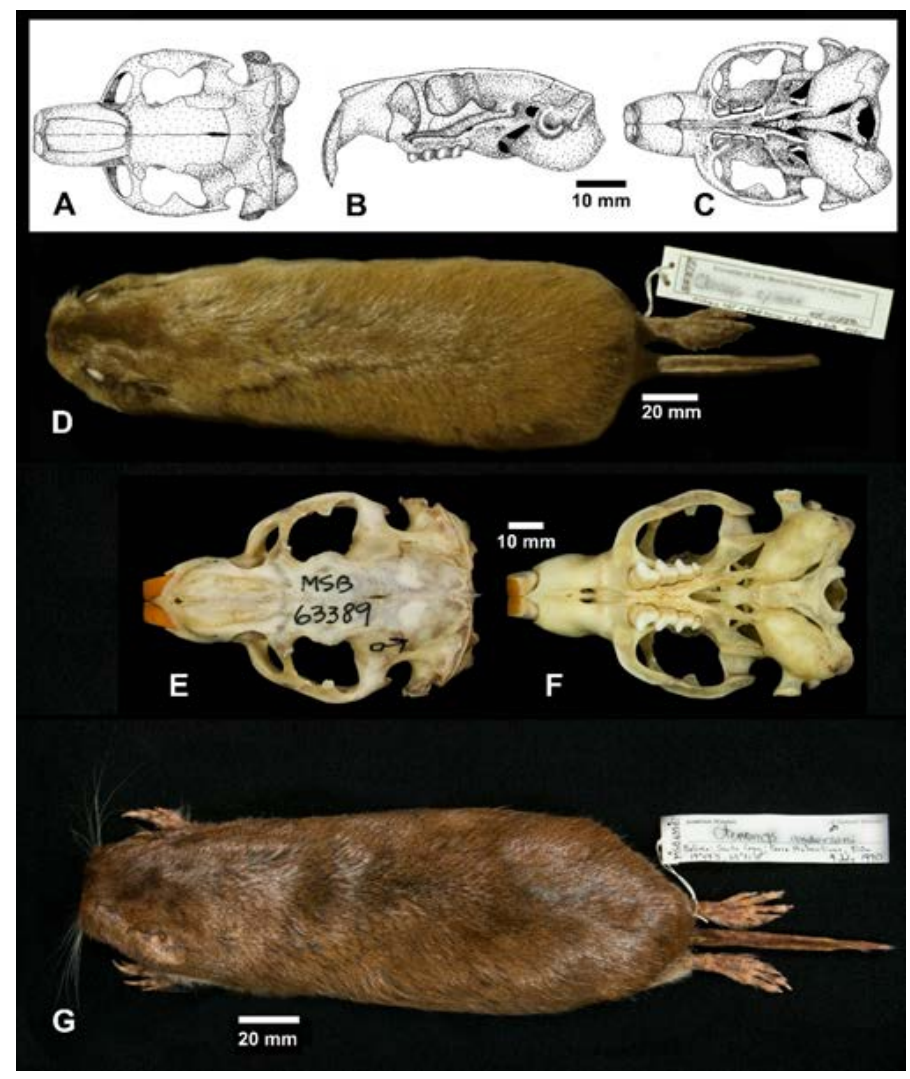

Figure 2. A-D. Ctenomys opimus Wagner 1848, Highland tuco-tuco or tuco-tuco Andino. A. Ink drawing of dorsal aspect of skull showing relatively inflated auditory canals and posteriorly protuberant auditory bullae. B. Left lateral view. C. Ventral view, Figure 2. E-G, Ctenomys andersoni Gardner et al. 2014, Anderson's tuco-tuco or Anderson's Cujuchi. E. Photo image of dorsal aspect. F. Photo of ventral aspect. G. Photo image of dorsal aspect of museum study skin.

\section{Ctenomys boliviensis Waterhouse, 1848}

(Figure 3 A, B, C, D; Map, Figure 9).

Common name: Bolivian tuco-tuco, cuhuchi, cujuchi.

Morphology: $(n=81)$ Body length 289; tail 77; hindfoot 42; ear 7; weight 329.

Individuals of this species are moderately large. The pelage is reddish brown, with darker areas mid-dorsally, especially on head and nape with a well-developed lighter colored collar extending ventrad from the pinnae. Regarding the skull, distinctive characters include the posterior position of the postorbital processes. A summary of the morphological characters for this species is given in Anderson et al. (1987), in addition, we follow Gardner et al. 2014 and regard C. goodfellowi Thomas 1921 as a synonym of C. boliviensis.

Distribution: Ctenomys boliviensis is found in the lowlands of the Department of Santa Cruz from 400 to $500 \mathrm{~m}$ (Anderson et al. 1987). The species has been recorded from approximately 25 separate localities in Bolivia, one cluster of records occurring around Santa Cruz de la Sierra and another in Santa Rosa de la Roca to the east. Our estimate using the SDM indicates there exists approximately 14,347 $\mathrm{km}^{2}$ of suitable habitat through the species range in Bolivia, with a core area around Santa Cruz de la Sierra and smaller suitable patches east and north, among which are collection localities of Santa Rosa de la Roca (Figure 9 C; Table 1). On average, bioclimatic data contributed more to the final ensemble model of this species, although soil variables also provide important contributions to the estimate.

Natural history: Cujuchis commonly occur throughout agricultural areas in the lowlands sometimes causing damage to crops, especially yucca (Manihot esculenta), corn (Zea mays), and other crop plants (Gardner and Salazar-Bravo, pers. obs. 1990). Individuals of C. boliviensis were found in lower densities in grasslands and seldom occurred in the forests, although some specimens have been collected from wooded areas (Thomas 1921; Anderson et al. 1987). Near the western border of its distribution along the Andean foothills, C. boliviensis is replaced by C. steinbachi (Anderson et al. 1987) and in some areas, these two species occur in close proximity (separated by only $7.5 \mathrm{~km}$ ). Individuals of Ctenomys boliviensis spend most of their time underground in burrows. Little scientific data are available on behavior and habits of this species, but observations by Gardner with Yates (pers obs. 1984, 1985) indicate that the Cajuchi is active throughout the 24 hour period with perhaps greater activity in early morning and late evening; at least one specimen was collected by hand around 11:00 am from sandy areas south of Santa Cruz de la Sierra. Anderson et al. (1987) also report that pregnant females have been recorded in May and June, with the number of embryos ranging from one to five (mean 1.7). Parasites - Ctenomys boliviensis is known to host the coccidian Eimeria opimi with a $36 \%$ prevalence in a sample of 236 individuals examined from near Santa Cruz de la Sierra (see summary in Gardner and Duszynski 1990). Pucu et al. (2014) report the flea species Gephyropsylla klagesi Rothschild, 1904 and Ectinorus galeanus Jordan, 1939 from this tuco-tuco. Recently, a new species of hookworm, Ancylostoma ctenomyos Drabik and Gardner 2019, was described (Drabik and Gardner 2019) from cajuchi specimens collected during our work that extended from 1984 - 2000 (Also, see summary of this nematode from C. steinbachi, below). Both lice (Phtheiropoios sp.) and nematodes of the genus Paraspidodera have been recorded and many of these are being described as new species.

Species Conservation/Preservation Status: This tucotuco has been categorized as a species of least concern (LC) by the IUCN (Dunnum and Bernal 2016) and is not listed in any threat category within Bolivia by the LRFSV. However, the geographic range of this species is expected to be significantly reduced by climate change under both employed scenarios, with a loss of around $78 \%$ of the suitable habitat area under the 4.5 RCP and a $26 \%$ loss under the 8.5 RCP (see map, Figure 11; Table 1). The milder expected change 
of the 8.5 RCP projection results from an expansion of suitable habitat to the east of the current range. The suitable habitat of the species has also suffered important habitat transformation with $47 \%$ of the natural and semi-natural areas of suitable habitat changing to agriculture or urban zones from 1993 to 2018 , leaving only about $40 \%$ of the suitable habitat under natural and semi-natural conditions (Table 2). Although it has been observed that this species can survive in or near agricultural land, it is likely that current and future land-cover/use changes will affect the long-term viability of $C$. boliviensis in Bolivia. Furthermore, less than $1 \%$ of the area of distribution of the species lies in protected areas (Caraballo et al. 2020) which in Bolivia includes two municipal parks: Orquídeas del Encanto and Laguna Represa Sapocó, both in Santa Cruz Department. Land cover changes, as well as the projected impact of climatic change on suitable habitat for this species suggest the need of more in-depth studies of habitat use by this species as well as additional studies on populations and estimates of long-term viability.

\section{Ctenomys conoveri Osgood, 1946}

(Figures 1 A, B; 3 E, F, G; Map, Figure 9)

Commonname: Conover's tuco-tuco, tuco-tuco del Chaco Morphology: $(n=4)$ Body length 474.75; tail 113; hindfoot 56; ear 14; weight 1178. Individuals of this species have the largest body size of any in the family Ctenomyidae with some adult males as heavy as $1,520 \mathrm{~g}$ (Figure $1 \mathrm{~A}, \mathrm{~B}$ ). Pelage of several individuals examined by us is relatively coarse with long shaggy fur (many hairs are longer than $20 \mathrm{~mm}$ ). The basal part of their dorsal hairs is pale grayish about $10 \mathrm{~mm}$ long, then there is a brownish part about 7 $\mathrm{mm}$, ending in blackish tips. Some longer guard hairs have paler tips. Overall color of dorsum is blonde-brown, some individuals with fur darker mid-dorsally, especially on head and nape, and around the mouth (Figure $1 \mathrm{~A}$; the venter is paler and more reddish. Hind foot is broad with welldeveloped combs (Figure $1 \mathrm{~B}$ ). The upper incisors are light Orange in color with shallow longitudinal grooves evident in anterior view (Figure $1 \mathrm{~A}$ ). A summary of skin and skull characters is given in Anderson et al. (1987).

Distribution: Ctenomys conoveri is distributed through the southern lowlands of Bolivia and where found is locally common in the Departments of Chuquisaca, Santa Cruz, and Tarija, as well as the Chaco region of Paraguay. This species has been reported from 15 separate collection localities in Bolivia, including southern Santa Cruz, eastern Tarija, and eastern Chuquisaca. The SDM predicts 29,000 $\mathrm{km}^{2}$ of suitable habitat through the species range in Bolivia (Figure 9; Table 1). On average, soil variables show higher contribution to the final model, suggesting that soil conditions significantly influence the distribution of the species.

Natural history: Ctenomys conoveri occurs in friable soils that are mostly sandy in composition. This species inhabits the Gran Chaco ecosystem. The specimens we collected in

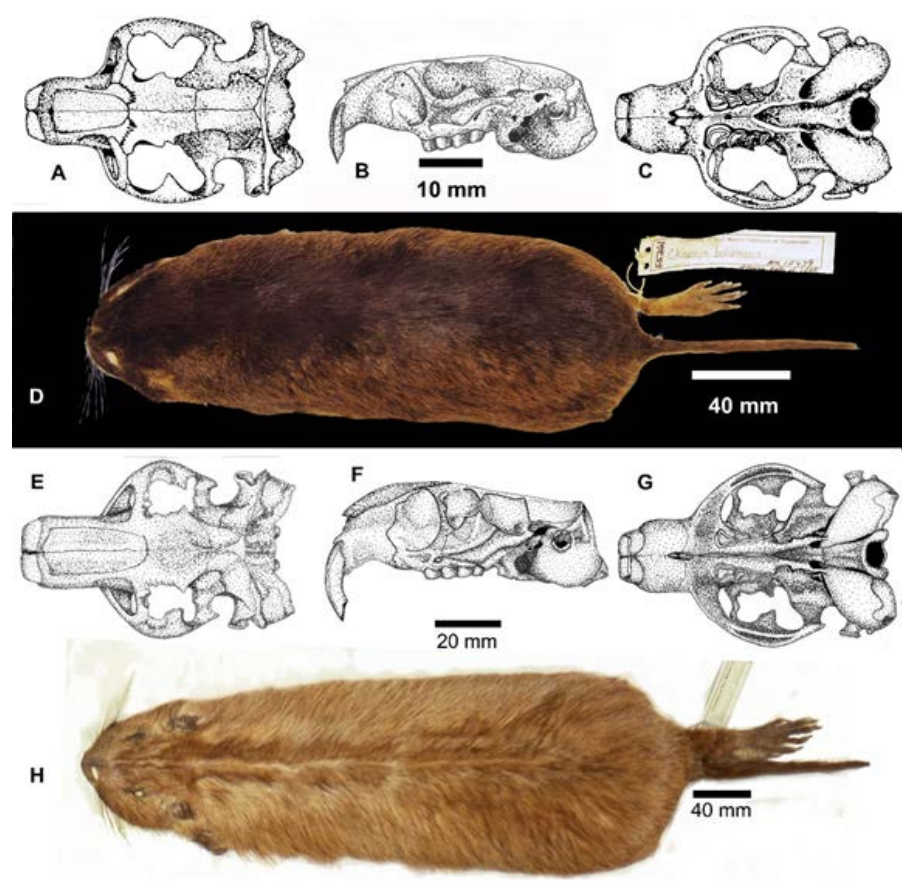

Figure 3. A-D Ctenomys boliviensis Waterhouse, 1848, Cuhuchi or Cujuchi. A. Ink drawing of dorsal aspect of skull showing robust bone architecture. B. Left lateral view of skull. C. Ventral view of skull. D. Dorsal view of skin. Figure 3. E-H, Ctenomys conoveri Osgood 1946, tuco-tuco del Chaco. E. Ink drawing of dorsal view of skull, F. Left lateral view of skull, G. Ventral view of skull.

1985 were easy to catch with number 1 or 2 leghold traps placed in the burrow system. We noted dozens of neatly cut green stems approximately the same length (8 to 15 $\mathrm{mm}$ long) that had been trimmed from small stems of trees or bushes, piled in the burrow system of one of the individuals we caught. Parasites - Coccidia Apicomplexa: Eimeriidae) identified as Eimeria opimi Lambert et al. 1988 were reported from one of three individuals collected in 1985 and studied by Gardner and Duszynski (1990). Chewing lice (Phtheiropoios sp.) that were obtained from specimens we collected are being studied and described. Nematode parasites of the genus Paraspidodera were also found infecting the cecum of most of the individual tuco-tucos that were collected. These are currently being described as new species.

Species Conservation/Preservation Status: This species is listed as Least Concern (LC) globally by the IUCN as well as within Bolivia by the LRFSV. The distribution of suitable habitat for the species in Bolivia is expected to expand to the east and north of the current distribution, resulting in an increase of $12 \%$ distribution area under the 4.5 RCP and $34 \%$ under the $8.5 \mathrm{RCP}$ scenario (Figure 11 ; Table 1). This is the only species of Ctenomys that has a geographic distribution that we project will expand under the expected global warming scenario. Less than $1 \%$ of the natural and semi-natural areas within the species distribution in Bolivia have suffered significant transformations since 1993, resulting in about $98 \%$ of the habitat remaining in at least seminatural conditions or pasture land that is conducive to proliferation of $C$. conoveri (Table 2). Nonetheless, the area is dissected by several small roads, and many habitats of this 


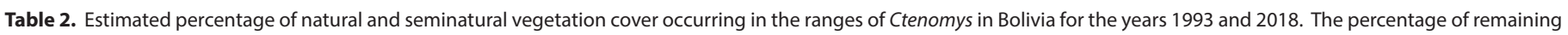
natural and seminatural vegetation cover lost through this 15 year period is also displayed.

\begin{tabular}{|c|c|c|c|c|}
\hline Species & Estimated range area $\left(\mathbf{k m}^{2}\right)$ & $\begin{array}{c}\text { \%Natural-seminatural } \\
\text { cover } 1993\end{array}$ & $\begin{array}{c}\text { \%Natural-seminatural } \\
\text { cover } 2018\end{array}$ & $\%$ Natural-seminatural lost \\
\hline Ctenomys opimus & 100,733 & 99.6 & 100 & 0.04 \\
\hline Ctenomys andersoni & 4,512 & 97.1 & 97 & 0.6 \\
\hline Ctenomys boliviensis & 14,347 & 74.7 & 40 & 47.0 \\
\hline Ctenomys conoveri & 28,936 & 98.7 & 98 & 0.5 \\
\hline Ctenomys erikacuellarae & 7,461 & 97.8 & 98 & 0.3 \\
\hline Ctenomys frater & 34,443 & 97.9 & 98 & 0.2 \\
\hline Ctenomys lessai & 4,556 & 95.5 & 95 & 0.4 \\
\hline Ctenomys leucodon & 8,382 & 98.4 & 98 & 0.2 \\
\hline Ctenomys lewisi & 2,087 & 98.4 & 98 & 0.7 \\
\hline Ctenomys nattereri & 43,495 & 99.3 & 97 & 1.8 \\
\hline Ctenomys steinbachi & 2,690 & 73.9 & 58 & 21.1 \\
\hline Ctenomys yatesi & 4,214 & 99.7 & 99 & 0.2 \\
\hline
\end{tabular}

species in Paraguay have suffered severe transformations from industrial agriculture (Caldas et al. 2015). Across the area occupied by this species about $15 \%$ of the range of C. conoveri overlaps with protected zones (Caraballo et al. 2020). In Bolivia, these areas include: Parque Nacional Aguarague, Area de Proteccion del Quebracho Colorado, and Reserva Natural El Corbalán, and the Monumento Natural - Muela del Diablo, near Boyuibe, Chuquisaca.

\section{Ctenomys erikacuellarae Gardner et al. 2014}

(Figure 4 A, B, C; Map, Figure 9).

Common name: Erika Cuellar's tuco-tuco, tuco-tuco de Erika Cuellar.

Morphology: $(n=69)$ Body length 259.2; tail 72.9; hindfoot 36.4; ear 7; weight 222.1. This is a medium-sized tucotuco with dorsal and ventral coloration well differentiated. The dorsum ranges from ochraceous orange to buckthorn brown except for the upper surface of the head and muzzle which is blackish brown. Most individuals with dark cap (fuscous black) on head, with dark fur running from just above the nose to at least neck. Mid-dorsal stripe of same dark color running posteriad mid-dorsally along back usually reaching rump.

The venter is drab brown or buffy brown and displays extensive white or light buff markings on inguinal, axillary and pectoral regions. The skull is strongly built, having strongly curved zygomatic arches. The rostrum is widest at the tip of premaxillaries giving a strongly robust look when observed from above. The upper incisors are large, robust, orange in color, and opisthodont; lower incisors are also orange in color.

Distribution: Erika Cuellar's tuco-tuco is known only from three localities situated on the eastern flanks in the Andes in the Cordillera Oriental. No species distribution model (SDM) was constructed for this species since not enough occurrence data to enable this type of analysis are yet available. The qualitatively estimated range of the species encompasses the valleys where the species occurs through an area of 7,461 km² (Figure 9; Table 2).

Natural history: These tuco-tucos occur in habitats consisting of friable soils, mostly in the floors of valleys ranging from a recorded low altitude of $810 \mathrm{~m}$. in the area of Monteagudo, Department of Chuquisaca to a recorded maximum of around 1,800 $\mathrm{m}$, near the Río Ciénega north east of Vallegrande, Santa Cruz Department in south-central Bolivia. From Gardner et al. (2014): "All three known localities are part of the ecological zone known as Bosques Secos Interandinos or Andean dry valleys (Ibisch et al. 2003; Lopez 2003). The locality designated " 2 km SW of Monteagudo" was on an agricultural experimental station that was, at the time, relatively protected as the vegetation was less disturbed inside the fenced station and was typical of the lower, eastern escarpments of the Andes in southern Bolivia (see: Ibisch et al. 2003). From the field-expedition field notes our team indicates: At the collection locality "5.5 km NNE of Vallegrande" on the Río Ciénega, the hillsides were covered with mesquite (Prosopis L.), columnar cacti (e. g., Trichocereus sp.), acacia (Acacia sp.), and Ximenia sp. The Río Ciénega runs through the valley and is surrounded by dense stands of shrubs and trees (Prosopis, etc.). The area was mostly converted to cropland and was, at the time, grazed heavily by livestock. The collecting locality at " $2 \mathrm{~km}$ E of Chuhuayaco" was similar in vegetation-type to that of Vallegrande. Parasites - Fleas identified by Pucu et al. (2014) as species of Rhopalopsyllus sp. and Polygenis sp. were collected from populations of $C$. erikacuellarae. Nematodes of the genus Paraspidodera were also obtained from Erika's tuco-tuco at time of collection; the nematodes are being described as new. In addition, lice (Phtheiropoios sp.) were also recovered as well as tapeworms. Tapeworms are rarely reported in the literature from any species of Ctenomys 
and we found cestodes in the small intestines of several individuals collected on the experiment station grounds near Monteagudo. These tapeworms, genus Raillietina are undescribed and we are currently finishing the descriptions of these worms.

Species Preservation/Conservation Status: Ctenomys erikacuellarae has not yet been evaluated by the IUCN or LRFSV. Few large-scale changes have occurred within the estimated distribution of the species during the period analyzed, with around $97 \%$ of the species range under natural or seminatural conditions (Table 2). Across the range of this species in Bolivia, about $48 \%$ of the area in which these tuco-tucos live is under some form of protection (Caraballo et al. 2020); these areas include: the Área de Protección Ambiental Serranía Cordillera de los Milagro, National park Iñao, area natural de manejo integrado Rio Grande Valles Crucenos, and the Zona de Inmovilizacion Forestal e Hídrica El Villar. Regardless, given its restricted distribution, the species conservation status requires close monitoring.

\section{Ctenomys frater Thomas, 1902}

(Figure 4 D, E, F; Map, Figure 9)

Common name: little Andean tuco-tuco, tuco-tuco pequeño de los Andes.

Morphology: $(n=7)$. Body length 250; tail 69; hindfoot 34; ear 8.4; weight $165 \mathrm{~g}$. Ctenomys frater is a mediumsized tuco-tuco, the subspecies occurring in Bolivia present brown dorsal coloration and dull buffy underparts. Also, see the excellent summary-description of this species by Cook et al. (1990).

Distribution: Ctenomys frater occupies suitable habitat in the Andean valleys of south eastern Bolivia in the departments of Chuquisaca and Tarija extending south into NW Argentina, including the provinces of Salta and Jujuy. The species distribution model for $C$. frater predicts $34,443 \mathrm{~km}^{2}$ of suitable habitat through Bolivia, with a large continuous suitable area in the eastern flanks of the Andes in Tarija and Chuquisaca and small patches of habitat further North up to Potosi and Oruro, where there are no records of the species at the moment (Figure 9; Table 1). On average, soil variables show greater contribution to the final model, suggesting that soil conditions appear to significantly impact the distribution of the species which can be expected for any subterranean rodent (Table 1). Variables that were investigated here included bulk density (fine earth) in kg / cubic-meter, clay content (0-2 micrometers) mass fraction in \%, soil organic carbon content (fine earth fraction) in $\mathrm{g}$ per kg, silt content (2-50 micrometer size range) mass fraction in $\%$, and sand content (50-2,000 micrometers) mass fraction in \%.

Natural history: Ctenomys frater occurs through a wide elevational range extending from $600 \mathrm{~m}$ in northwestern Argentina (Thomas 1919; Olrog and Lucero 1981) to approximately 4,300 m in central Bolivia (Anderson 1997). Specimens of $C$. frater were collected by our team from
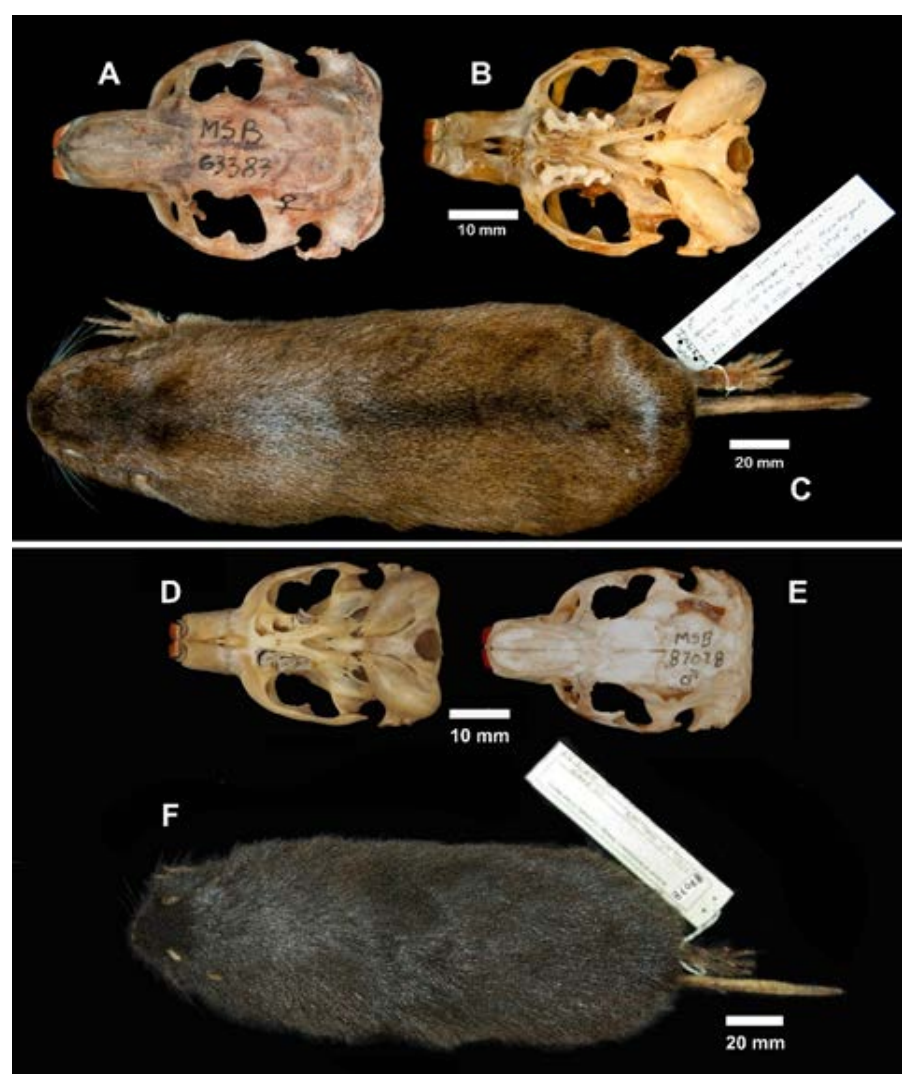

Figure 4. A-C Ctenomys erikacuellarae Gardner et al. 2014, Erika Cuellar's tuco-tuco or tuco-tuco de Erika Cuellar. A. Dorsal view of the skull showing the rostrum is widest at the tip of premaxillaries and the strongly curved zygomatic arches. B. Ventral view of the skull. C. Dorsal view of skin. Figure 4. D-F, Ctenomys frater Thomas 1902 Little Andean tuco-tuco or tuco-tuco de los Andes. D. Ventral view of the skull. E. Dorsal view of the skull. F. Dorsal view of the skin.

steep grassy hillsides $(2,700 \mathrm{~m})$ in the Andes at a locality called $8 \mathrm{~km}$ west, by road of Rancho Tambo $\left(21^{\circ} 27^{\prime} \mathrm{S} ;-64^{\circ}\right.$ $19^{\prime} \mathrm{W}$, estimated with map), while other specimens of the same species were found at elevations above $4,300 \mathrm{~m}$ in the department of Potosi. At the locality called Tapecua $\left(21^{\circ}\right.$ $26^{\prime} 13.4^{\prime \prime} \mathrm{S} ;-63^{\circ} 55^{\prime} 0.12^{\prime \prime} \mathrm{W}$, data from GPS), visited by our collection party in July 1991 and again in 1995, additional specimens of Ctenomys frater were collected. All of these specimens, collected on 4, June 1995 were extremely dark, their fur matching well the color of the soil where these mammals were found to be abundant. The animals were found to be living in friable, but not sandy soil on extremely steep hillsides under the canopy of trees. The habitat changed dramatically from the time we first visited Tapecua in 1991 compared to our subsequent visit in 1995. In 1995, we found that domestic goats had been introduced into the area and the vegetation was cut up to the level that a goat can reach. For much of the time when we were at both Rancho Tambo and Tapecua, Andean Condors were very common. Some condors landed within 5 meters of us as we worked our traplines on the steep hillsides at the locality designated $8 \mathrm{~km}$ west, by road of Rancho Tambo; the condors soared nearby during the middle of the day at Tapecua. At the Tapecua locality, tuco-tuco-trapping was difficult as moving up and down the hillsides required much effort. Parasites - Fleas (Ectinorus galeanus Jordan 1939) were collected by our field party in 1986 from 3 individual tuco- 
tucos at $8 \mathrm{~km}$ west, by road from Rancho Tambo. Coccidia identified as Eimeria opimi were collected from this same locality and identified by Gardner and Duszynski (1990). Nematodes of the genus Paraspidodera were collected from specimens obtained from both the Rancho Tambo and Tapecua localities, these are being described as new. Species Preservation/Conservation Status: This tuco-tuco has been categorized as a species of least concern (LC) by the IUCN (Vivar 2017) and is listed as data deficient by the LRFSV. The distribution of suitable habitat for $C$. frater in Bolivia is expected to be reduced $8 \%$ under the 4.5 RCP and $9 \%$ reduction under the 8.5 RCP scenario (see Map 11 ; Table 1). Few large scale changes have occurred within the estimated distribution of the species during the period analyzed, with around $97 \%$ of the species range under natural or semi-natural conditions (Table 2). About $15 \%$ of the range of $C$. frater is protected in more than 20 areas in Bolivia (Caraballo et al. 2020).

\section{Ctenomys lessai Gardner et al. 2014}

(Figure 5 A, B, C; Map, Figure 10)

Common name: Lessa's tuco-tuco, tuco-tuco de Lessa.

Morphology: $(n=9)$, Body length 238; tail 64; hindfoot 32; ear 6.6; weight $176 \mathrm{~g}$. Ctenomys lessai shares a common ancestor with $C$. conoveri (see phylogeny in Gardner et al. 2014). Because this is such a unique and isolated species we directly quote Gardner et al. (2104) in the description of the skins and skulls: "Pelage dense, fine, soft, about 5-20 $\mathrm{mm}$ long over back and rump. Color of dorsal pelage olive brown to buffy brown, ventral pelage cinnamon buff, some individuals with ventral fur olive buff. Dorsally, darkest fur a clove brown in central diffuse dorsal stripe, more prominent anteriorly on head and fading posteriad... ...Small light area of cinnamon buff fur, just posterior to and below the pinnae, evident in most individuals. Collar not evident in specimens examined." In contrast to the well developed collars of differently colored fur extending from the pinnae ventrad in both C. boliviensis and C. steinbachi there is no collar in the gular region of $C$. lessai. In describing the skull, Gardner et al. (2104) state: "Upper incisors with enamel a light pale yellow ocher to ivory yellow color. Enamel initially white in unexposed roots, changing to yellow ocher with mottled yellowing slightly on frontal surfaces of exposed parts of incisors. Sometimes appearing mottled in frontal view with white showing through. Enamel of lower incisors yellow ocher in color. Mandible relatively delicate."

Distribution: This species is known only from the type locality near a place $0.5 \mathrm{~km}$ south of Lluthu Pampa, $17^{\circ} 45^{\prime} \mathrm{S}$; $-64^{\circ} 59^{\prime} \mathrm{W}, 2,700 \mathrm{~m}$. elevation in the Andean portion of the department of Cochabamba (Figure 10).

Natural history: Specimens of this tuco-tuco were collected from burrow systems at elevations ranging from 2,500 to $2,750 \mathrm{~m}$. The area from where specimens were secured was open grassland habitat near a running stream with remnant stands of Polylepis sp. These tuco-tucos appear to be diurnal as most of the captures occurred during daylight hours. Parasites - From the original collection material obtained on 30 and 31 May 1991, both ectoparasites and endoparasites were collected by our field crew. Lice (Phtheiropoios sp.) are currently being studied and the fleas have been identified and reported as Ectinorus galeanus Jordan, 1939 and Sphinctopsylla inca Rothschild, 1914 by Pucu et al. (2014). Nematodes of the genus Paraspidodera were collected from the cecum of these mammals and these are currently being described as a new species.

Species Conservation/Preservation Status: Individuals of this species have been collected only from the type locality and this species has not been evaluated by the IUCN or the LRFSV. The area surrounding the type locality has suffered less than $1 \%$ large scale landscape changes in the period analyzed, but including previous changes, $95 \%$ of the area remains as natural or semi-natural habitat (Table 2). Almost $50 \%$ of the area surrounding the collection localities is currently listed as protected, including both Parque Nacional Amboró and Parque Nacional Carrasco (Caraballo et al. 2020).

\section{Ctenomys leucodon Waterhouse, 1848}

(Figure 5 D, E, F; Map, Figure 10)

Common name: white-toothed tuco-tuco, tuco-tuco de dientes blancos.

Morphology: $(n=3)$ body length 223; tail 67; hindfoot 31; ear 5; weight 160 . White-Toothed tuco-tucos are small in size and very reddish in color (Figure $5 \mathrm{D}, \mathrm{E}, \mathrm{F}$ ). Their fur is a rich Buckthorn Brown and is thick over the body and the ears are well-furred with darkly colored skin on the pes (Figure $5 \mathrm{D}$ ). The pale, relatively narrow and proödont upper incisors are noteworthy. See the excellent summary of the morphology of this species in Cook et al. (1990).

Distribution: Ctenomys leucodon occurs in a relatively small area generally south of Lake Titicaca at elevations of about 3,850 m. in the department of La Paz, in Bolivia but also west of the southern part of the lake in Peru (two collection locality records; Figure 10). No SDM was constructed for this species since not enough occurrence data points have been recorded in museums to enable this type of analysis. The qualitatively estimated range of the species encompasses the valleys where the species occurs through an area of $8,382 \mathrm{~km}^{2}$.

Natural history: Habitat of the tuco-tuco de dientes blancos consists of flat puna with compact soils that are friable only with difficulty as soil is held together by masses of grass roots that bind the soil well. In the areas where these were collected are dispersed bunch grasses that dot the landscape. Associated throughout the area and especially where the $C$. leucodon colonies were found were many common yellow toothed cavys (Galea musteloides), but, even though they occurred syntopically at the locality (11.5 $\mathrm{km}$ west of San Andres de Machaca, $17^{\circ} 00^{\prime} \mathrm{S}$; $-69^{\circ} 04^{\prime} \mathrm{W}$; $3,800 \mathrm{~m}$.) we did not observe these two species of mammals using the same burrow systems at this locality. The Tuqui- 
tos de Dientes Blancos were located in isolated colonies sometimes separated by distances as great as kilometers. No data on colony size could be determined from our work. First encountering these animals in 1986, some individuals of $C$. leucodon exhibited a high-pitched whistle vocalization on several occasions. Individuals of this species seemed to spend more time at burrow openings than did other species of Bolivian Ctenomys as several were observed with their heads out of the burrow systems for a relatively long period of time. These animals appear to occur in moving landscape patches or colonies called "tucales" that move through space and time and appear to operate as mini soil plows that enable higher diversity of plants to grow in the soil where the mammals turn over the soils. In the field, members of our expeditions observed higher diversity of both plants and mammals among and in tucales. In Peru, C. leucodon appears to be the least common species of Ctenomys, occurring in a restricted area west of Lake Titicaca (see map, Figure 10). In August, one female with one embryo and seven females with no embryos were recorded (Anderson 1997). Parasites - Three individuals were examined for the presence of coccidia (Eimeria) by Gardner and Duszynski (1990) but were found to be uninfected. Two species of fleas were identified from material collected by our team in 1993 including Ectinorus galeanus Jordan, 1939 and Tetrapsyllus tristis Johnson 1957 (see report by:

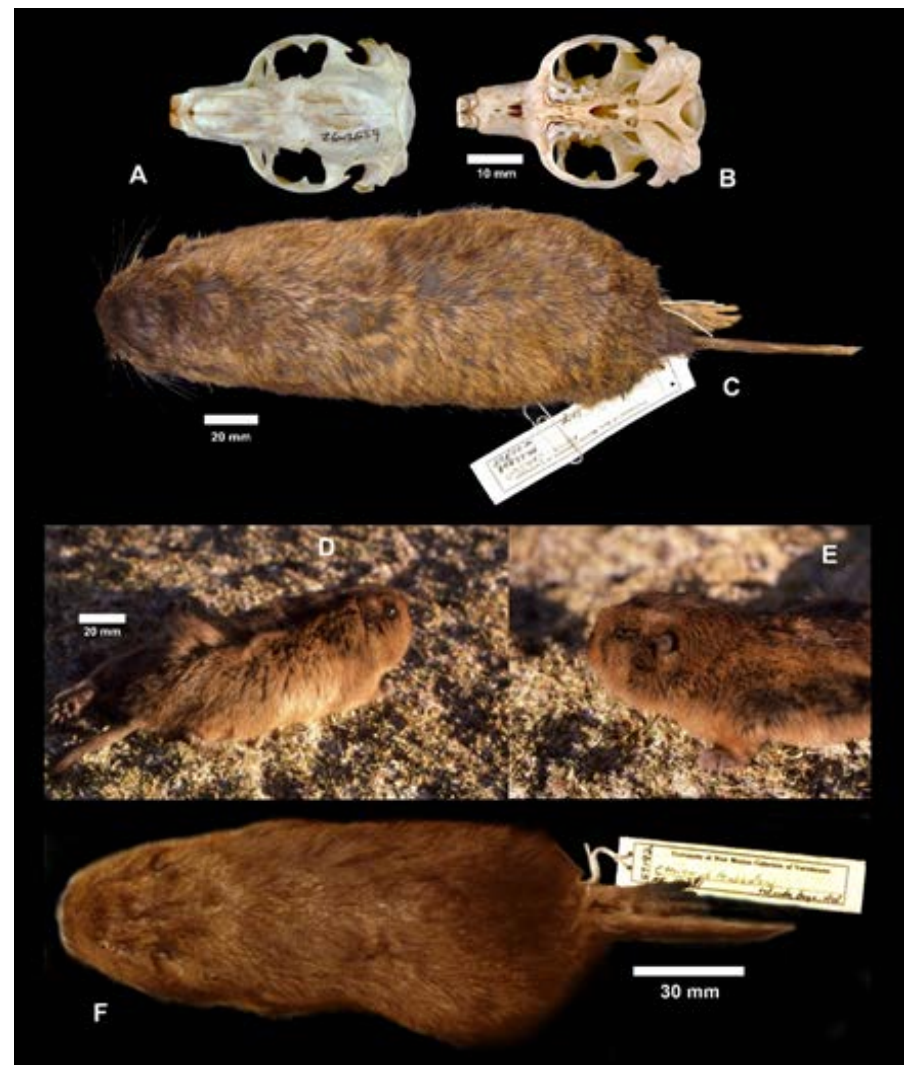

Figure 5. A-C Ctenomys lessai Gardner et al. 2014, Lessa's tuco-tuco or el tuco-tuco de Lessa. A. Photo image of dorsal aspect of skull, note particularly delicate rostrum. B. Photo image of ventral aspect of skull. C. Photo image of dorsal view of museum study skin of C. lessai. Figure 5. D-F. Ctenomys leucodon Waterhouse, 1848, White-Toothed tucotuco, el tuco-tuco de Dientes Blancos. D. Photo image of right lateral side of a living $C$. leucodon. E. Photo image of anterior left lateral side of same individual as in 5 D, F. Photo image of dorsal aspect of museum study skin.
Pucu et al. 2014). A nematode called Pudica sp. was identified by Gardner pers. obs. and lice (Phtheiropoios sp.) were collected along with beetles of the family Staphylinidae from individuals of $C$. leucodon by our field expeditions in 1986 and 1993 (Anderson 1997 and Pucu et al. 2014). Species Conservation/Preservation Status: The species is listed as Least Concern by the IUCN and as data deficient by the LRFSV. Although $98 \%$ of the distribution area comprises pasture, natural or semi-natural covers (Table 2), almost none $(0.1 \%)$ of the protected areas that are established overlap the range of this species (Caraballo et al. 2020).

\section{Ctenomys lewisi Thomas, 1926}

(Figure 6 A, B, C, D, E; Map, Figure 10)

Common Name: Lewis's tuco-tuco, tuco-tuco de Lewis. Morphology: $(n=15)$ Body length 268; tail 76; hindfoot 39; ear 8; weight $291 \mathrm{~g}$. Thomas (1926) characterized C. lewisi as a large reddish-brown species with unusually proodont incisors. He stated: "Ctenomys leucodon has similarly proodont incisors, but these (C. leucodon) are comparatively slender, are not so strongly flattened in front, and are almost unpigmented." Because Thomas (1926) compared C. leucodon with C. lewisi, we will make some similar comparisons here. Individuals of $C$. lewisi that we trapped at the Iscayachi locality were of a rich dark black/brown color dorsally and lighter with grey ventrally. The dorsal coloration appears to closely match the color of the soil of the area when it is moist. The pinnae are sparsely furred and pink in color (Figure $6 \mathrm{D}$ ) in sharp contrast to the dense reddishbrown-black fur on the pinnae of C. leucodon (Figure 6D, E). See also the excellent summary of the morphology of this species in Cook et al. (1990).

Distribution: Ctenomys lewisi is known only from the highlands of Tarija in the valley near Iscayachi (elevation of collecting localities in 1986 was 3,400 m) with the Serrania de Sama rising rapidly to the east to about $4,000 \mathrm{~m}$ over a distance of $6 \mathrm{~km}$. from the collecting site (Figure 10).

Natural history: This species was first collected from burrows in wet stream banks, which led Thomas (1926) to suggest $C$. lewisi had semi-aquatic habits. No such habit has been suggested for any other species of tuco-tuco and some, but not all, of the specimens captured by members of our expedition in 1986 near Iscayachi were trapped from burrows in damp soil near the Rio Tomayapo. There was no indication that any of the 15 animals we collected at the Iscayachi locality lived in or even very near water. Parasites - From 6 of 8 individuals examined for coccidian parasites in the feces, oocysts representing Eimeria opimi were found (Gardner and Duszynski 1990). Nematodes of the genus Paraspidodera were also recovered from the cecum of several individuals and these are being described as new. In addition, chewing lice (Phtheiropoios sp.) were recovered from this species at the Iscayachi locality and further up the mountain near Sama. These are also being described. Fleas were not recovered during collection of the mammals. 
Species Conservation/Preservation Status: Ctenomys lewisi was listed as a Species of Least Concern (SLC) by the IUCN (Roach and Naylor 2016a) and as data deficient by the LRFSV. Approximately, $98 \%$ of the distribution range of this species comprises natural and semi-natural land cover (Table 2), but with heavy grazing by domestic animals and $21 \%$ of its estimated distribution range is covered by protected areas including the Reserva Biológica Cordillera de Sama and Parque Natural y Área de Manejo Integrado El Cardón (Caraballo et al. 2020).

\section{Ctenomys steinbachi Thomas, 1907}

(Figure 6, F - I; Map, Figure 10)

Common names: Steinbach's tuco-tuco, tuco-tuco de Steinbach.

Morphology: $(n=46)$ Body length 293; tail 81; hindfoot 43; ear 7; weight $315 \mathrm{~g}$. The skin of this species has a light Black pelage dorsally with grizzled or mixed whitish and blackish ventral pelage. Well developed light grey collar extending ventrally from each pinna. See Anderson (1997) for an excellent summary of the morphology of this species.

Distribution: Ctenomys steinbachi is found only in the department of Santa Cruz, west of the Rio Grande. Individuals of this species have been collected from 8 separate localities ranging from 300 to $500 \mathrm{~m}$. in altitude. Steinbach's tuco-tuco suitable habitat comprises $2,690 \mathrm{~km}^{2}$ (Figure 10; Table 1). The environmental requirements of this species are different from those of $C$. boliviensis, resulting in very little suitable habitat overlap between the two species despite their close geographical distance. Individuals of this species have been collected as close as $15 \mathrm{~km}$ in geographic proximity of populations of $C$. boliviensis at and at slightly higher elevations than is inhabited by C. boliviensis along the eastern foothills of the Andes near Parque Nacional Cerro Amboro (Anderson et al. 1987).

Natural history: Steinbach's tuco-tuco has been recorded from open savanna areas, closed canopy areas with yucca and banana and areas that have been disturbed by sugarcane plantations, cattle grazing and other agricultural activities. The soil where these animals occur is darker and contains much less sand than the areas occupied by $C$. boliviensis in the area where these two species occur in proximity. Parasites - Of 72 specimens of Steinbach's tuco-tuco examined for the presence of the protistan parasite Eimeria sp., none were found to be passing oocysts when they were collected in contrast to a relatively high prevalence of the parasites found in other species of Ctenomys (Gardner and Duszynski 1990). Drabik and Gardner (2019) described Anyclostoma ctenomyos from duodenum in the small intestine of Ctenomys steinbachi collected from Bolivia, Departamento de Santa Cruz: $2 \mathrm{~km} \mathrm{~S}$. Caranda, by road, $\left(17^{\circ} 33^{\prime} 0^{\prime \prime} \mathrm{S} ;-63^{\circ}\right.$ $31^{\prime} 48^{\prime \prime} \mathrm{W}, 345 \mathrm{~m}$ ) (note that this species of nematode was also recovered from C. boliviensis) on August 14, 1987. The prevalence of this nematode was $6 / 13=46 \%$. Nematodes of the genus Paraspidodera have also been collected from $C$.
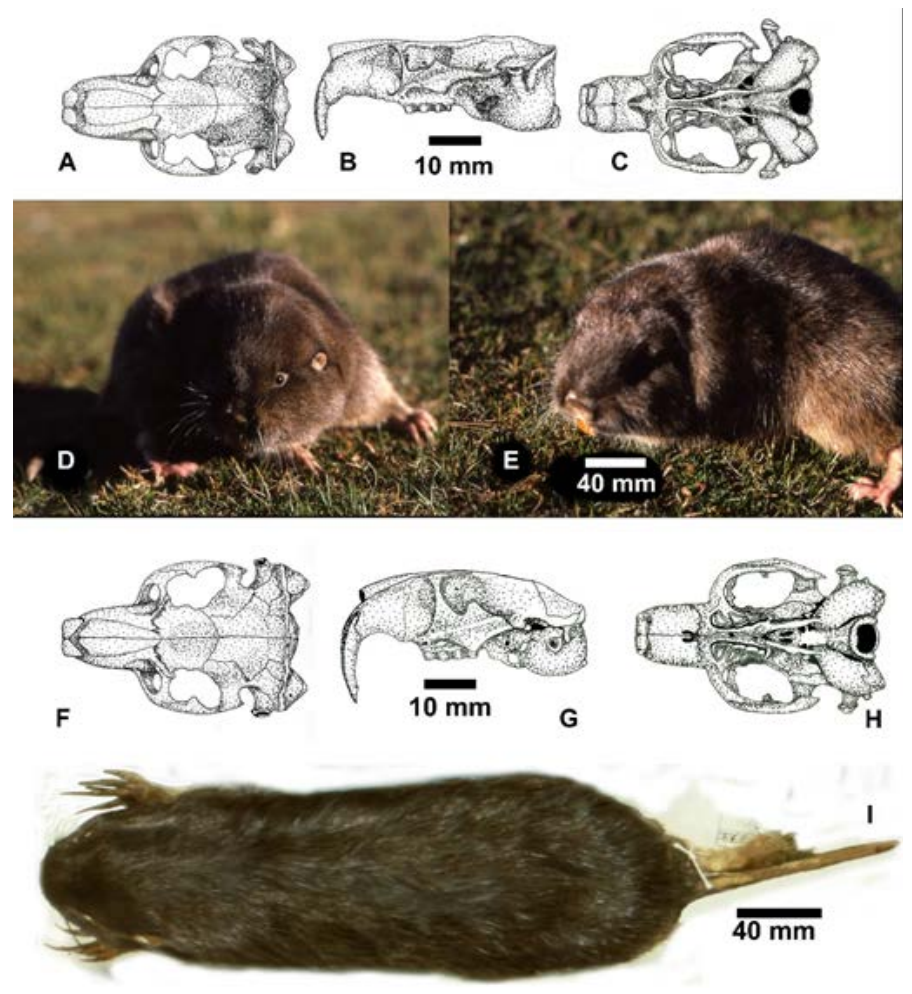

Figure 6. A-E. Ctenomys lewisi Thomas, 1926, Lewis's tuco-tuco, tuco-tuco de Lewis. A. Ink drawing of dorsal aspect of skull. B. Left lateral view. C. Ventral view, note extremely long auditory canals and rear-turned auditory bullae. Figure 6. F-I Ctenomys steinbachi Thomas, 1907, Steinbach's tuco-tuco or tuco-tuco de Steinbach. F. Ink drawing of dorsal aspect of skull, G. Left lateral view of skull. H. Ventral view of skull. I. Photo image of dorsal aspect of skull of $C$. steinbachi.

steinbachi, and chewing lice of the genus (Phtheiropoios sp.) were collected from individuals of this species and these are being described elsewhere as new.

Species Conservation/Preservation Status: Ctenomys steinbachi is categorized as a SLC by the IUCN (Roach and Naylor 2016b). However, in Bolivia this species is categorized as near threatened (NT) by the LRVSB because of the lack of recent collection records and the coincidence of the species range with areas of intense habitat conversion into both urban and agricultural uses. Similar to the situation for C. boliviensis, this species is predicted to experience severe contraction in suitable habitat areas, with a $61 \%$ and $58 \%$ reduction under the GCM 4.5 and GCM 8.5, respectively (Table 1 ). In total, about $21 \%$ of the remaining natural and semi-natural vegetation cover was lost through the range of the species since 1993, which leaves only $58 \%$ of the species distribution area as natural or semi-natural conditions (Table 2 ). In addition, only $4 \%$ of the species range is under protection. Given the endemic status, magnitude of observed habitat degradation, and expected impact of climate change; this species should be closely monitored, and we feel strongly that Ctenomys steinbachi should be assigned to a higher IUCN threat category. We recommend a higher threat category partly because of the problematical list of so-called protected areas in the department of Santa Cruz, Bolivia. Caraballo et al. (2020) shows that the area in which C. steinbachi occurs are overlapped by at least three 
areas with some degree of ecological protection. However, examining these areas shows that that they appear to provide minimal protection for native species, this is because, from aerial views, it can be seen that these areas are covered with urban sprawl or consist of intensive industrial agriculture with most of the natural areas being obliterated by humans. The areas that are listed as protected include: Parque de Protección Ecologica Río Piraí and the Área Protegida Municipal Curichi La Madre, Parque Regional Lomas de Arena see Caraballo et al. (2020).

\section{Ctenomys nattereri Wagner 1848}

(Figure 7 A - H; Map Figure 10)

Common name: Natterer's tuco-tuco, tuco-tuco de Natterer.

Morphology: (Taken from Wilson et al. 2017) Body length 245; tail 71; hindfoot 54; ear 11; No information on weight. This is a relatively large species of Ctenomys that presents a shiny brown dorsal coloration capped by a dark dorsal stripe comprised of black spots. The venter is black with white spots, especially in the axillary and inguinal regions. On the specimen examined, the claws of the forefeet are particularly long, reaching $16 \mathrm{~mm}$. The specimen of $C$. nattereri that we present here is derived from the skull of (AMNH37121) collected on 24 Feb, 1914 by G. K. Cherrie on an expedition with Theodore Roosevelt and Cândido Mariano da Silva Rondon through the area of what would eventually become Rondonia, both upper and lower incisors are a dark orange, the skull is robust.

Distribution: The distribution of the species includes the eastern lowlands of Bolivia in the department of Santa Cruz east into Brazil (Figure 10). In Bolivia, tuco-tuco specimens from four localities in Santa Cruz have been assigned to $C$. nattereri. Based on an analysis of cyt-b phylogeny and genetic distances, Gardner et al. (2014) assigned the populations near Roboré, San Jose de Chiquitos, and San Ramón to C. nattereri. Besides Bolivia, the species has been recorded in the states of Mato Grosso and Rondônia in Brazil.

Natural history: Little is known of the habitats or behavior of this tuco-tuco. Parasites - Nematodes recorded by our collecting expeditions from this tuco-tuco in Bolivia include species of the genera Paraspidodera and Trichuris.

Species Conservation/Preservation Status: This species has not been evaluated by the IUCN or the LRFSV although IUCN treats $C$. nattereri as a synonym of $C$. boliviensis (see Dunnum and Bernal 2016). The range estimated from the abovementioned localities has lost around $2 \%$ of its natural and semi-natural land cover since 1993 (Table 2). Approximately $32 \%$ of the species range appears to be under some protection category (Caraballo et al. 2020) but at the current time, little information is known of the habits of these tucotucos. The areas in Bolivia in which some protection of this species is given include: Area Natural de Manejo Integrado San Matías and the Area Protegida Municipal San Rafael.

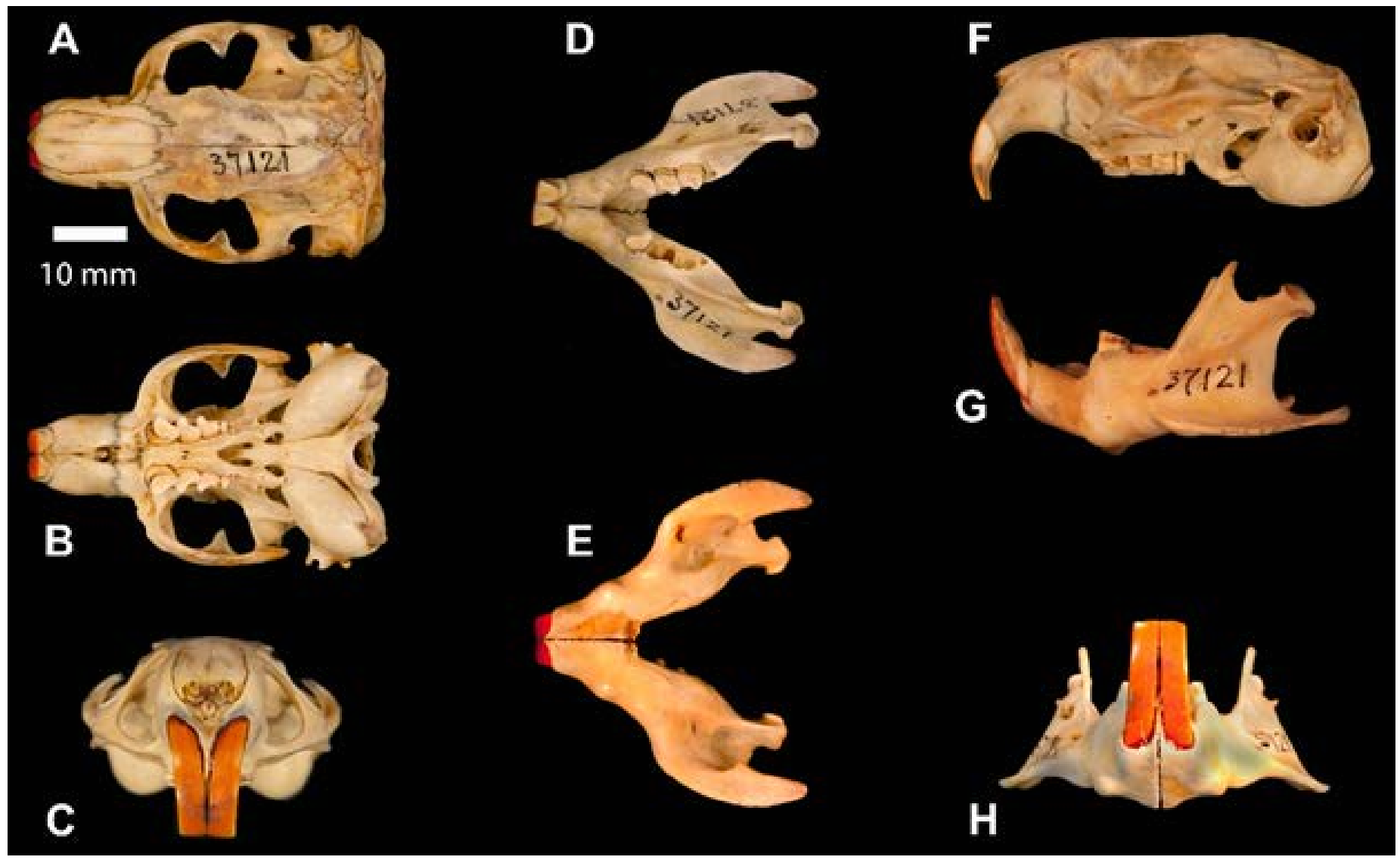

Figure 7. A-H. Photo images of the skull and jaw of Ctenomys nattereri Wagner 1848, Natterer's Tuco-tuco or tuco-tuco de Natterer. A. Dorsal view shows the robust skull. B. Ventra

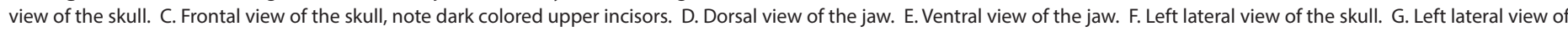
the jaw. H. Frontal view of the jaw displaying the dark incisors. 
Ctenomys yatesi Gardner et al. 2014

(Figure 8 A, C, F - I, Map Figure 10)

Common Name: Yates' tuco-tuco, tuco-tuco de Yates.

Morphology: $(n=3)$ Body length 209 ; tail 58; hind foot 32; ear 4; weight $96 \mathrm{~g}$. This species possesses a dense, fine, soft fur; dorsum with fur ranging from an ochraceous orange to buckthorn brown, hairs dark colored, except last 2.5 or $3 \mathrm{~mm}$ which are a distinctly lighter shade of the same color. Most individuals present a dark cap (Fuscous Black) on their heads. Color of ventral pelage is more sharply set off from dorsal in some individuals. Ears sparsely covered with short, brownish hairs, not contrasting conspicuously with color of head. Forefoot with a well-developed pollex, other four digits bearing long, basally closed claws. The skull is robust and wide. The interorbital region has squared margins and the frontals are widest at the level of connection of zygomatic arch, lateral to the posterior/anterior sutures of the frontals, nasals and maxillaries.

Distribution: Ctenomys yatesi is known only from the type locality, 7 kilometers north and 38 kilometers west of Roboré in southeastern Santa Cruz Department (Figure 10).

Natural history: Nothing is known of the natural history of Yates' tuco-tuco. The habitat was in fields of Yucca.
Species Conservation/Preservation Status: The species has not yet been evaluated by the IUCN or LRFSV. There have not been evident agriculturally based large-scale land-cover changes around the type locality of $C$. yatesi (Table 2), and only about $13 \%$ of the surrounding area is protected and includes only the Reserva Departamental Valle de Tucavaca (Caraballo et al. 2020). Nonetheless, because it appears that this species has a very restricted distribution, close monitoring is warranted.

Results of species distribution modeling for 5 species of Bolivian Ctenomys for changes in habitat suitability under greenhouse gas emission scenarios 4.5 and 8.5. For the 5 species of tuco-tucos for which we had sufficient data (i. e., numbers of individuals collected throughout the range of the species) with which to produce SDMs including C. opimus, C. boliviensis, C. conoveri, C. frater, and C. steinbachi, the model results were robust and statistically significant as evaluated by the pROC metric (Table 1). The habitat suitability approximation out to year 2070 was made using the median projected suitability (MPS). The MPS enabled us to predict suitable habitat for the species with different levels of global greenhouse gas emission. Using this aspect of the model we evaluated the effect of climatic and soil-related variables on potential distribution of these species (see figures 11 and 12).

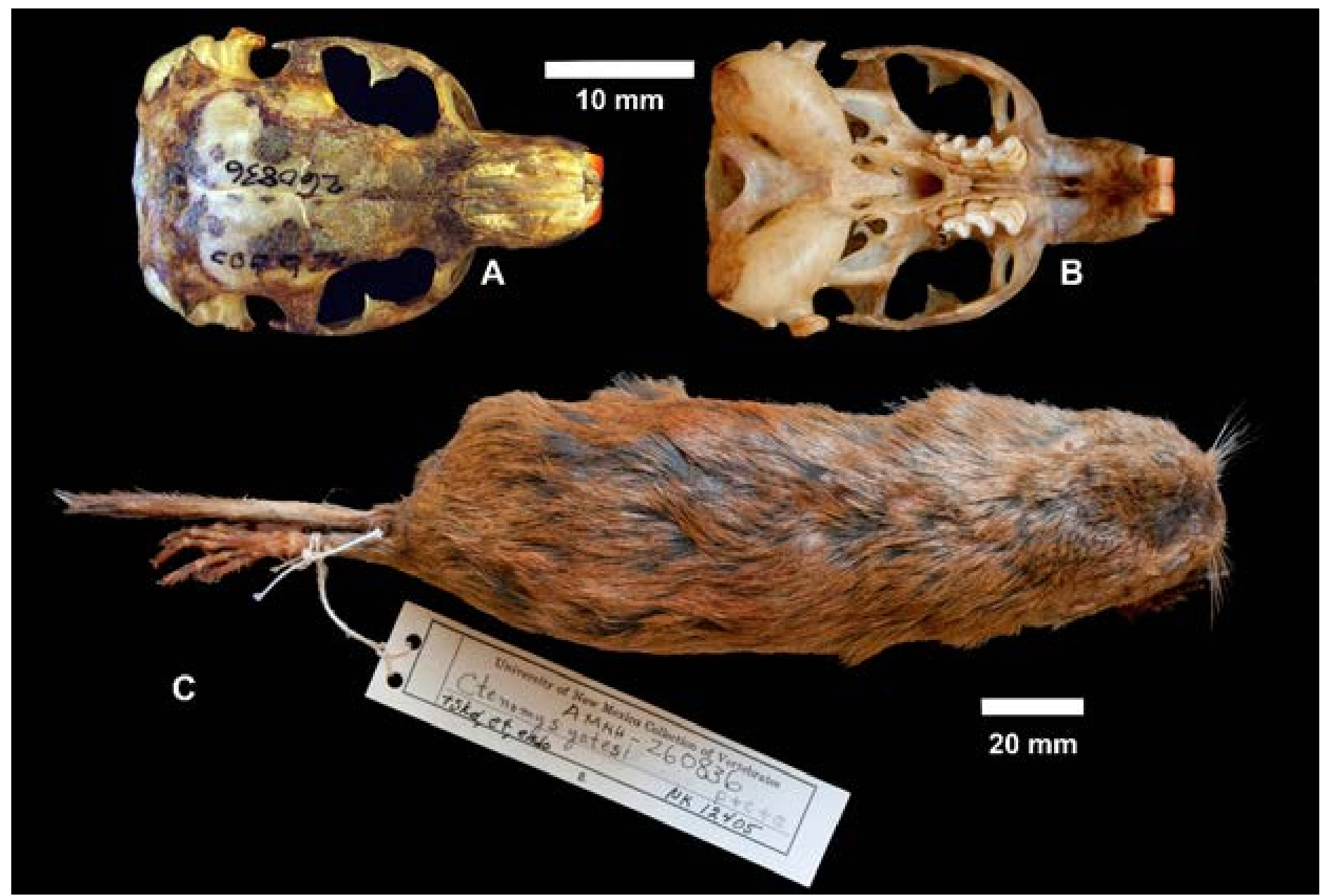

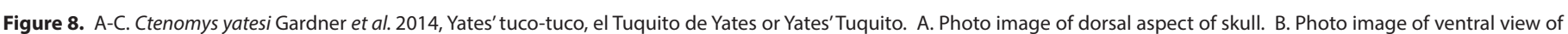
skull. C. Photo image of dorsal aspect of museum study skin. 


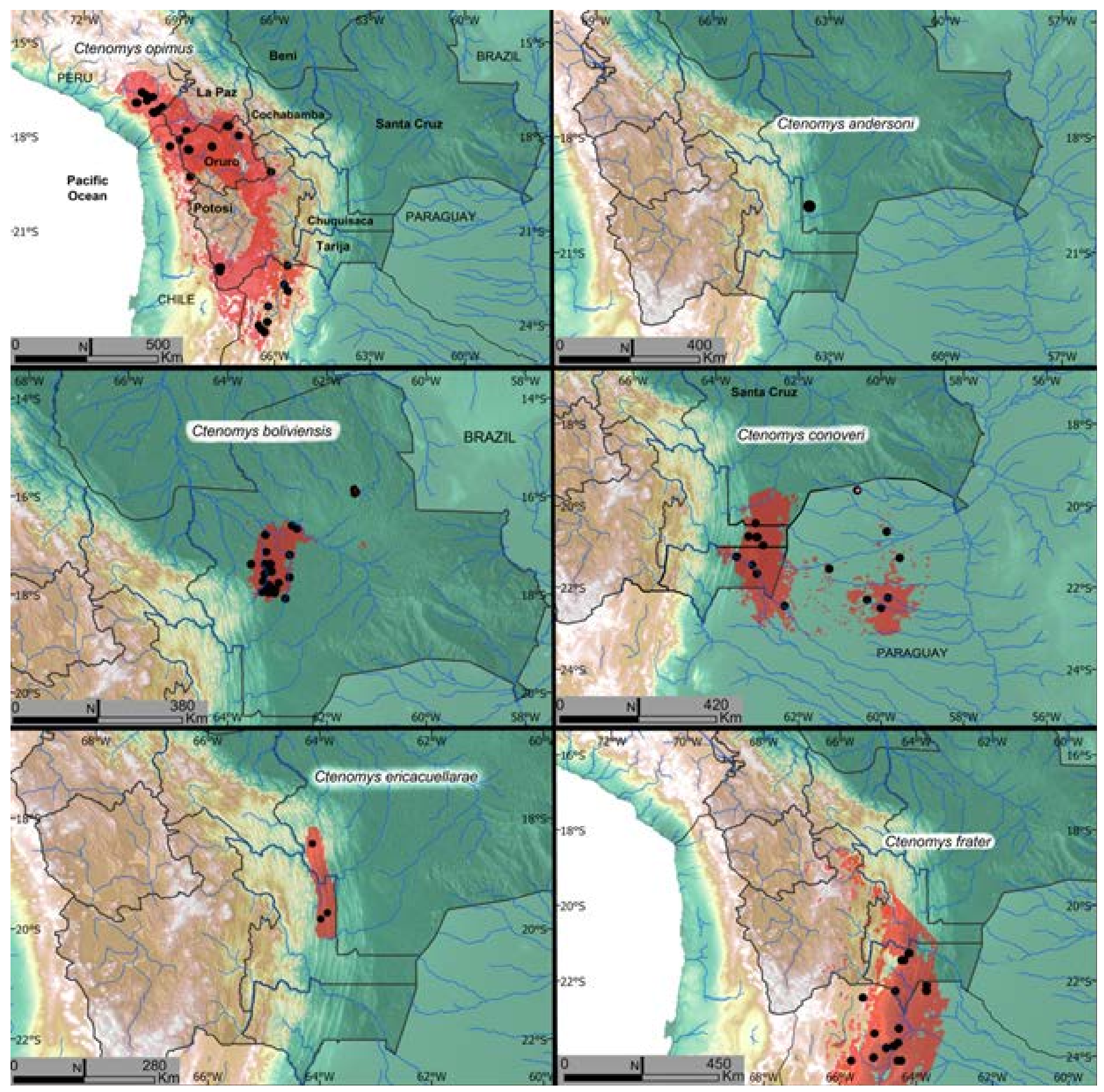

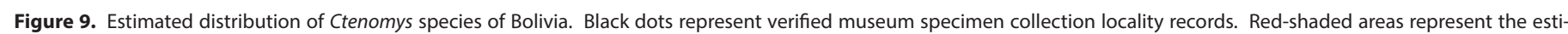

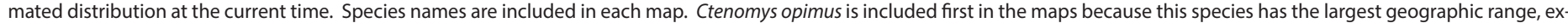

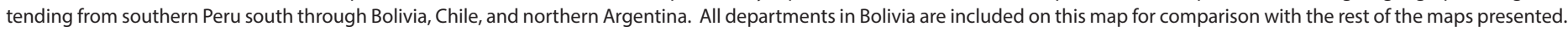

\section{Discussion}

An altitude-area optimization (not shown) onto the tree indicates that the probable common ancestor of the Ctenomys now occurring in Bolivia had an origin in high altitude areas of the Andes. It appears that tuco-tuco populations have been moving into open habitats, becoming isolated, re-united, and isolated again at geological time scales in the continually changing and evolving landscape of the central-eastern Andes of Bolivia. The greatest single factor that appears to be influencing the evolutionary trajectory of these rodents in the mountains is a component of the Andes called the Central Andean Backthrust belt (McQuarrie et al. 2005) that has created a dynamic erosional landscape resulting in incredibly diverse habitats ranging from cloud forest to cactus studded hillsides and valleys over only a few kilometers of straight-line geographic distance (Gardner et al. 2014; Unzueta 1975). Gardner and Ruedas (2019) showed, via optimization of occupied altitude of tuco-tuco species onto the phylogenetic tree of the ctenomyid species in Bolivia, that there was a striking correlation 
between the phylogeny and the age of origin of the eastern front-range mountain ridges of the Andes. The crustal folding from west to east combined with simultaneous and continuous erosion and riverine cutting of the north-south ridges appears to have resulted in episodes of repeated isolation and subsequent speciation in these rodents.

By applying species distribution models to predict suitable habitat for the known species of tuco-tucos in Bolivia within their range of distribution and evaluating the effect of climatic and soil-related variables on potential species distribution, we found that all the models resulted in robust predictions as indicated by the $\mathrm{pROC}$ ratios (Table 1). Not surprisingly, because of the fossorial/subterranean habit of these mammals, we found that soil variables have excellent predictive power and performed well in two of the five species for which their distributions were modeled, showing little difference in contribution to model performance with bioclimatic variables. We found higher average weight for the models when we including soil variables, indicating the utility of using these variable in the understanding of the habitat requirements of Ctenomys and probably other species of subterranean animals (see Figures 11 and 12).

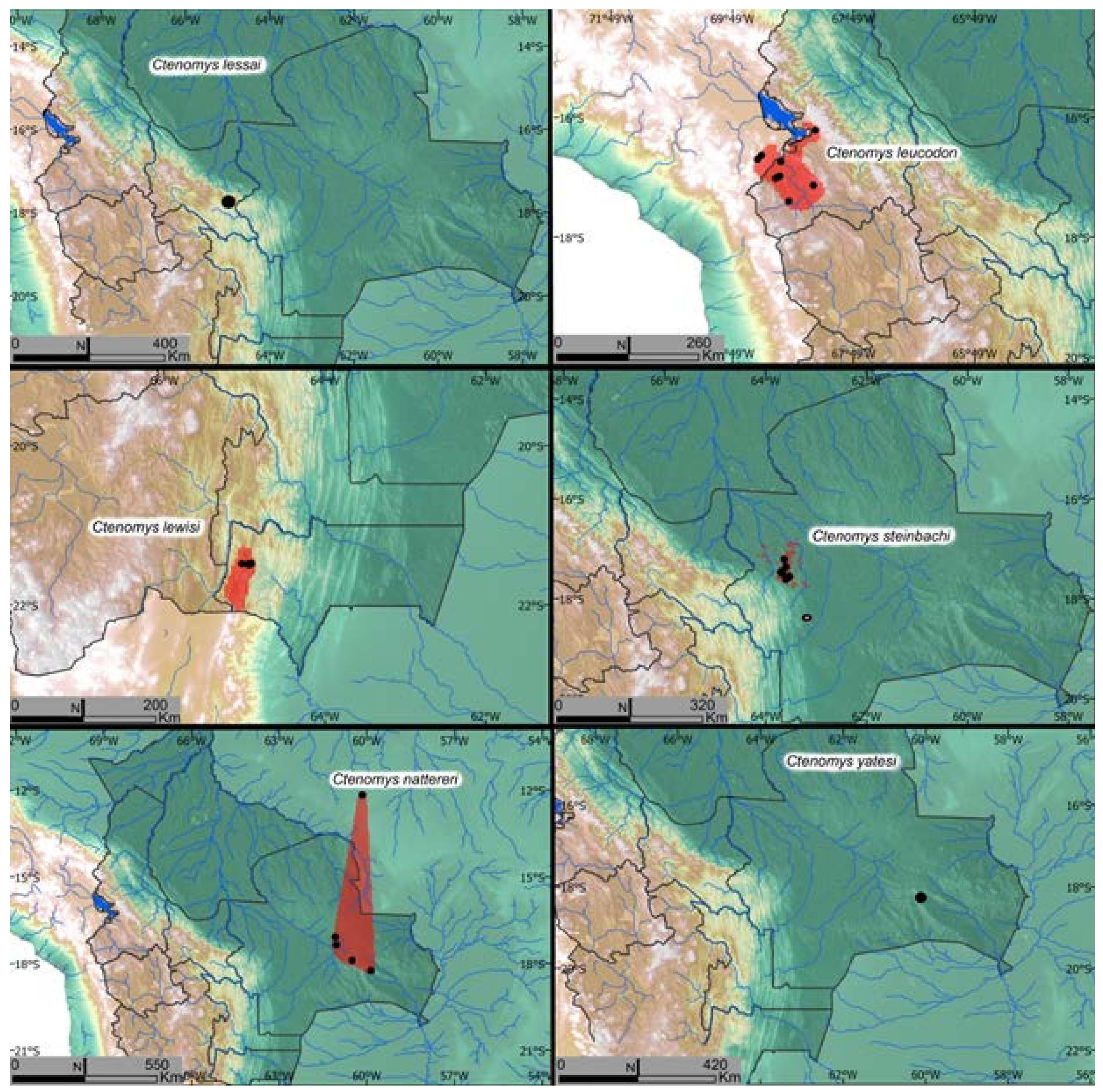

Figure 10. Estimated distribution of Ctenomys species of Bolivia. Black dots represent specimen collection localities. Red shaded areas represent the estimated distribution. Species names are included in each map. 


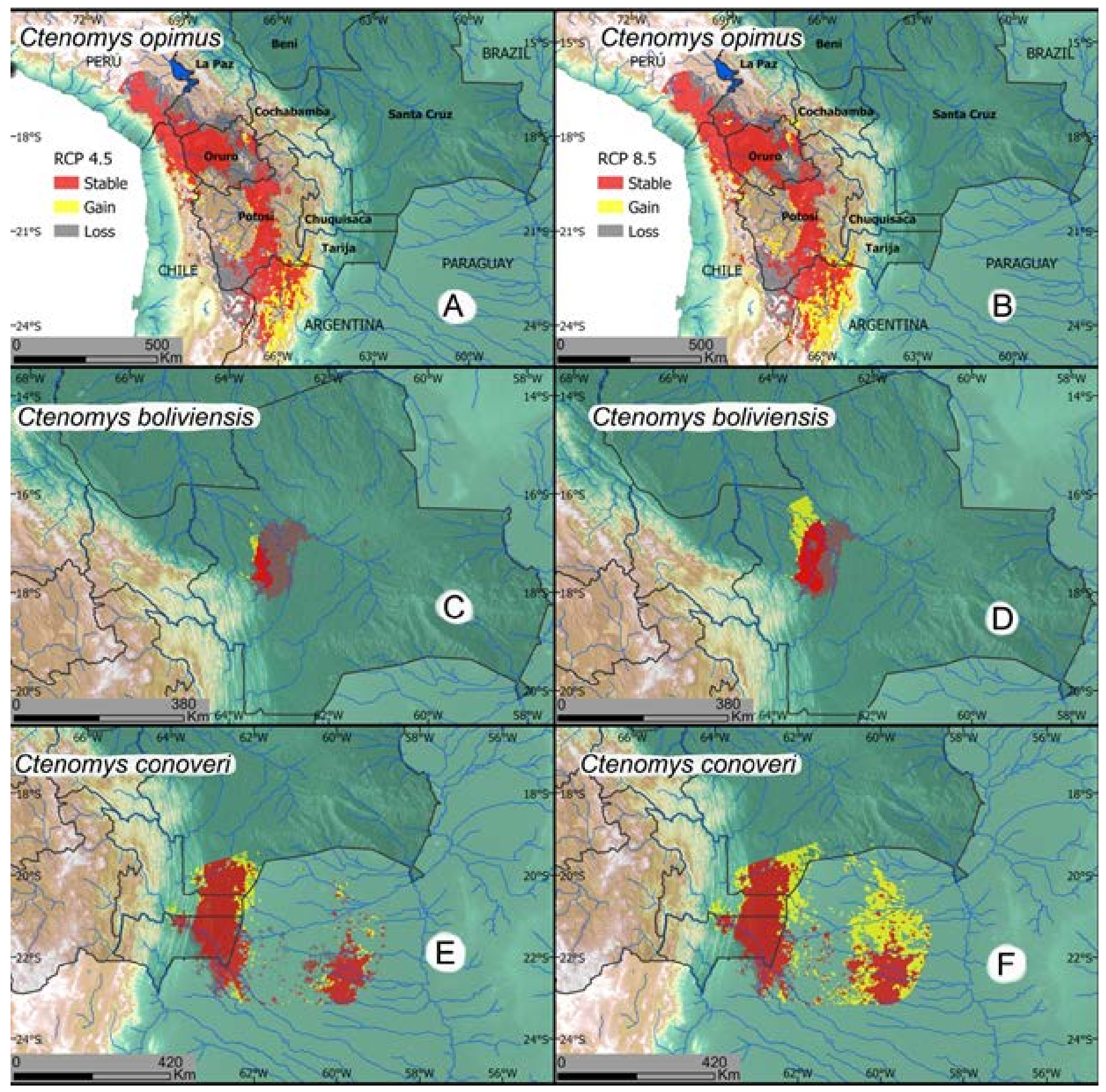

Figure 11. Projected changes in habitat suitability for 2070 under the 4.5 and 8.5 greenhouse gases emission scenarios. The 2070 suitable habitat is estimated for an assemble model

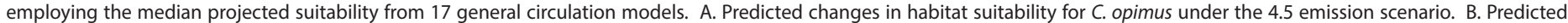

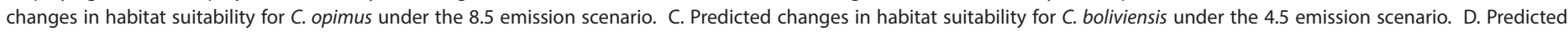

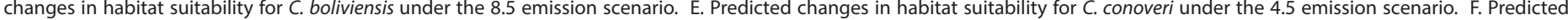
changes in habitat suitability for $C$. conoveri under the 8.5 emission scenario.

Three of the five species that were model using ENM are expected to suffer significant range contractions by the year 2070 under both of the global carbon emission scenarios evaluated herein. Two of these species occur in the lowlands of the department of Santa Cruz (C. steinbachi and C. boliviensis) and one on the altiplano (C. opimus). Nonetheless, the extrapolations of suitable habitat distributions for the year 2070 should be considered with care as these estimates assume that the species will not adapt to new environments, perhaps because of complete niche conservatism, and that future environmental conditions nature are predicted to be analogous or comparable to current conditions (Elith and Leathwick 2009).

This study highlights the need for detailed conservation assessments and monitoring of tuco-tuco's in Bolivia as most of the species have already, or will soon experience, significant loss in habitat with concomitant fragmentation of their populations due to anthropogenic land cover 
change exacerbated by rapidly changing climatic conditions. In addition to these factors, the known geographic ranges of Bolivian tuco-tuco species (except for C. opimus) are small in spatial geographic extent, with three species known only from their type localities and in seven cases, a very small proportion of their estimated or actual distribution range is in some sort of protected area.

The analysis presented here suggests that $C$. steinbachi (because of its restricted range) and perhaps $C$. boliviensis should be moved into a higher IUCN threat category than their current IUCN allocation. This higher IUCN category is suggested because more than $20 \%$ of their original geographic ranges have been significantly transformed by human activities. The anthropogenically mediated destruction of their habitats combined with predicted range contractions due to global warming portends the impending ecological and biodiversity catastrophe that is now tak- ing place world-wide (Ceballos et al. 2020). In addition to these factors, the currently known geographic ranges of both $C$. steinbachi and C. boliviensis show very little overlap with any true protected areas $(<5 \%)$ and because much of the geographic ranges of these two species are near or in path of the rapidly expanding urban area of Santa Cruz de la Sierra, we expect additional pressure especially on these two species.

As presented here, the uses of ENMs and SDMs combined with broad-scale and intensive biological surveys of the mammalian fauna of Bolivia (Anderson 1997) will enable future students of biodiversity to have a basis for additional focussed studies. As the atmosphere of our earth continues to heat due to anthropogenically generated greenhouse gasses, unexpected effects on the species of mammals on the earth will be manifested (Ceballos et al. 2020). We hope that this work on documenting and eventually providing an

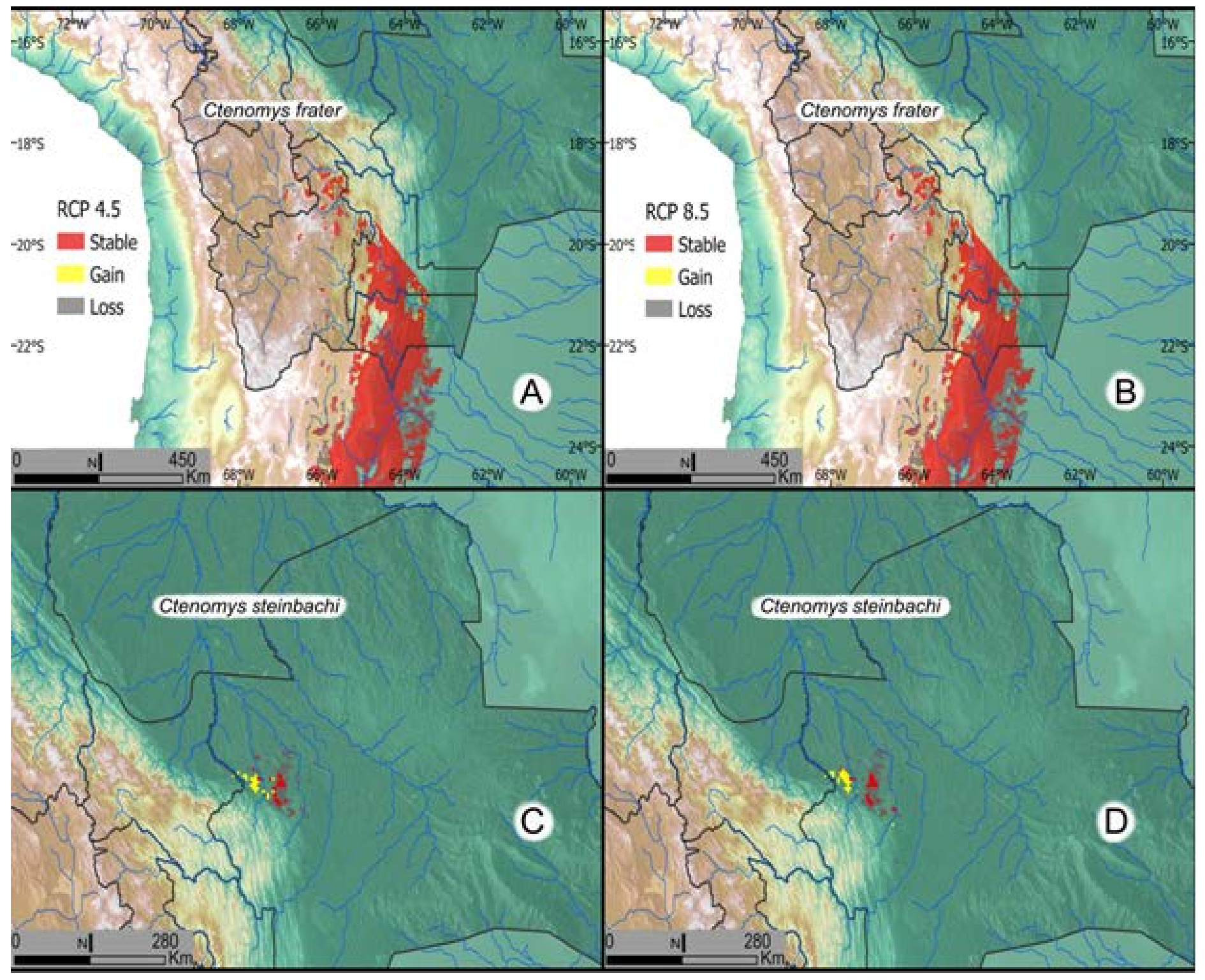

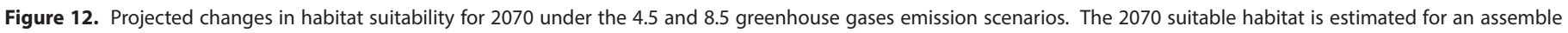

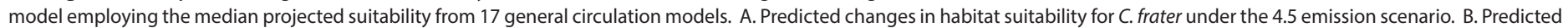

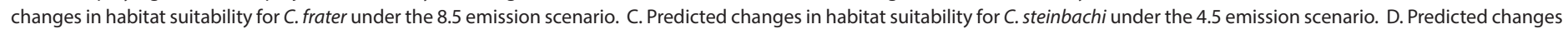
in habitat suitability for C. steinbachi under the 8.5 emission scenario. 
understanding of the delicate balances of how mammals interact with their environment over geographic space will provide a model for future research. At the very least, this work will provide a baseline from which additional studies can be formulated, proposed, funded, and carried out. In his "Mammals of Bolivia," Syd Anderson (1997, p 3) stated about his book: "This work is dedicated to the hypothesistesters of this world. Everything concluded here is subject to further testing. I expect much of this information to be substantiated, but not everything." We consider the current work to cohere to the way Syd approached his studies and our hypotheses, presented herein, and because they are based on museum specimens, will be available for testing far into the future. We feel that the prospects of viable biodiversity on our earth will be sustained if we are able to recruit new researchers walking the path of Syd and testing some of the hypotheses presented herein and generating new hypotheses along the way.

\section{Acknowledgments}

This work was funded in part by the National Science Foundation awards to Sydney Anderson, Terry L. Yates, Scott L. Gardner, Joseph A. Cook, and Jorge Salazar-Bravo (BSR8612329 to SLG; BSR-9024816 to SLG; DEB-9496263 to SLG; DEB9631295 to SLG; DEB-0097019 to SLG; DEB0717214 to SLG; DBI-0646356 to SLG; BSR 89-20617 to TLY; BSR 90-15454 to TLY, SA, and JAC; INT-9417252 to TLY and JSB) and from NATO Collaborative Research Grant (CRG No. 920612, to $\mathrm{SLG}$ ). Collaborating institutions in Bolivia included the Universidad Autónoma Gabriel René Moreno, the Zoológico Municipal Fauna Sudamericana (both of Santa Cruz de la Sierra), the Colección Boliviana de Fauna of the National Museum of Natural History, La Paz, and the Bolivian Academy of Sciences, La Paz. Noel Kempff Mercado, late director of the Zoológico Municipal Fauna Sudamericana (Santa Cruz de la Sierra), was instrumental in assisting our work from 1984-1986. All images made by SLG with special thanks to the late Lynn Hertel for assistance with inked drawings. This paper was improved substantially by the constructively critical comments of two anonymous reviewers.

\section{Literature cited}

Aiello-lammens, M. E., R. A. Boria, A. Radosavljevic, B. Vilela, AND R.P. Anderson. 2015. spThin: an R package for spatial thinning of species occurrence records for use in ecological niche models. Ecography 38: 541-545.

Anderson, S., T. L. Yates, ANd J. A. Cook. 1987. Notes on Bolivian mammals 4: the genus Ctenomys (Rodentia: Ctenomyidae) in the eastern lowlands. American Museum Novitates 2891:1-20.

Anderson, S. 1997. Mammals of Bolivia: taxonomy and distribution. Bulletin of the AMNH $231 \mathrm{pp}$.

Ashe, J. S., R. M. Timm, And M. H. Gallardo. 1996. Systematics, distribution, and host specificity of Edrabius fauvel (Insecta: Coleoptera: Staphylinidae). Proceedings of the Biological Society of Washington 109:731-743.
Barve, N., V. Barve, A. Jiménez-valverde, A. Lira-noriega, S.P. Maher, A.T. Peterson, J. Soberón, and F. Villalobos. 2011. The crucial role of the accessible area in ecological niche modeling and species distribution modeling. Ecological Modelling 222:1810-1819.

Bidau, C. J. 2006. Familia Ctenomyidae. Pp. 212 -231, in Mamíferos de Argentina. Sistemática y distribución (Bárquez,R. J., M. M. Díaz, and R. A. Ojeda, eds.). Sociedad Argentina para el Estudio de los Mamíferos. Tucumán, Argentina.

Bidau, C. J. 2015. Family Ctenomyidae Lesson, 1842. In: Mammals of South America 2:818-877.

Brant, S. V., AND S .L. Gardner. 1997. Two new species of Litomosoides (Nemata: Onchocercidae) from Ctenomys opimus (Rodentia: Ctenomyidae) on the Altiplano of Bolivia. Journal of Parasitology 83:700-705.

Breiner, F. T., A. Guisan, A. Bergamini, and M. P. Nobis. 2015. Overcoming limitations of modelling rare species by using ensembles of small models. Methods in Ecology and Evolution 6:1210- 1218.

Breiner, F. T., M. P. Nobis, A. Bergamini, and A. Guisan. 2018. Optimizing ensembles of small models for predicting the distribution of species with few occurrences. Methods in Ecology and Evolution 9:802-808.

Busch, C., C. D. Antinuchi, J. C. del Valle, M. J. Kittlein, A. I. Malizia, A. I. Vassallo, and R. R. Zenuto. 2000. Population ecology of subterranean rodents. Pp 183-226, in Life Underground: The Biology of Subterranean Rodents (Lacey E. A., J. L. Patton, and G. N. Cameron, eds). University of Chicago Press. Chicago, Illinois.

Caldas, M. M., D. Goodin, S. Sherwood, J. M. Campos Krauer, and S. M. WISELY. 2015. Land-cover change in the Paraguayan Chaco: 2000-2011. Journal of Land Use Science 10: 1-8.

Campbell, L.P., C. Luther, D. Moo-llanes, J. M. Ramsey, R. Danislozano, And A. T. Peterson. 2015. Climate change influences on global distributions of dengue and chikungunya virus vectors. Philosophical Transactions of the Royal Society B: Biological Sciences 370:20140135

Caraballo, D. A., S. L. López, A. A. Carmarán, and M. S. Rossi. 2020. Conservation status, protected area coverage of Ctenomys (Rodentia, Ctenomyidae) species and molecular identification of a population in a national park. Mammalian Biology 100:33-47.

Castillo, A., M. Cortinas, and E. P. Lessa. 2005. Rapid diversification of South American tuco-tucos (Ctenomys: Rodentia: (tenomyidae): Contrasting mitochondrial and nuclear intron sequences. Journal of Mammalogy 86:170-179.

Ceballos, G., P. R. Ehrlich, and P. H. Raven. 2020. Vertebrates on the brink as indicators of biological annihilation and the sixth mass extinction. Proceedings of the National Academies of Sciences of the United States 117:13596-13602.

Cobos, M. E., A. T. Peterson, N. Barve, and L. Osorio-Olvera. 2019. kuenm: an R package for detailed development of ecological niche models using Maxent. PeerJ 7:e6281.

Cook, J. A., S. Anderson, And T. L. Yates. 1990. Notes on Bolivian mammals 6: the genus Ctenomys (Rodentia: Ctenomyidae) in the highlands. American Museum Novitates 2980:1-27.

Cook, J. A., AND T. L. Yates. 1994. Systematic relationships of the tuco-tucos, genus Ctenomys (Rodentia: Octodontidae). Journal of Mammalogy 75: 583-599.

Cook, J. A., AND E. P. Lessa. 1998. Are rates of diversification in subterranean South American tuco-tucos (genus Cteno- 
mys, Rodentia: Octodontidae) unusually high? Evolution 52:1521-1527.

Darwin, C. R. 1860. Journal of researches into the natural history \& geology of the countries visited during the voyage round the world of H.M.S. 'Beagle' under the command of captain Fitz Roy, R. N. John Murray. Albemarle St., London.

Di Cola, V., O. Broennimann, B. Petitpierre, F.T. Breiner, M. D'amen, C. Randin, R. Engler, J. Pottier, D. Pio, A. Dubuis, L. Pellissier, R. G. Mateo, W. Hordijk, N. Salamin, and A. Guisan. 2017. Ecospat: an R package to support spatial analyses and modeling of species niches and distributions. Ecography 40:774-787.

Drabik, G. O., and S. L. Gardner. 2019. A new species Ancylostoma (Nemata: Strongylida: Ancylostomatidae) from two species of Ctenomys in lowland Bolivia. Journal of Parasitology 105:904-912.

Dunnum, J., ANd N. Bernal. 2016. Ctenomys boliviensis (errata version published in 2017). The IUCN Red List of Threatened Species 2016: e.T5798A115079917. https://dx.doi. org/10.2305/IUCN.UK.2016-3.RLTS.T5798A22192171.en. Downloaded on 03 May 2020.

Dunnum, J., J. Vargas, N. Bernal, N. Zeballos, and E. Vivar. 2016. Ctenomys opimus. The IUCN Red List of Threatened Species 2016: e.T5818A22194246. https://dx.doi.org/10.2305/IUCN. UK.2016-2.RLTS.T5818A22194246.en. Downloaded on 06 June 2020.

EISENBERG, J. F. 1963. The behavior of heteromyid rodents. University of California Publications in Zoology 69: 1-114.

Elith, J., AND J. R. LeathWICK. 2009. Species distribution models: Ecological explanation and prediction across space and time. Annual Review of Ecology, Evolution, and Systematics 40:677-697.

Fick, S. E., AND R. J. Hiumans. 2017. WorldClim 2: new $1 \mathrm{~km}$ spatial resolution climate surfaces for global land areas. International Journal of Climatology 37:4302-4315.

FourCade, Y., J. O. EnGLeR, D. RödDER, AND J. SECondI. 2014. Mapping species distributions with MAXENT using a geographically biased sample of presence data: A performance assessment of methods for correcting sampling bias. PLoS One 9: e97122.

Freitas, T. R. O. 2006. Cytogenetics status of four Ctenomys species in the south of Brazil. Genetica 126:227-235.

GardneR, S. L. 1991. Phyletic coevolution between subterranean rodents of the genus Ctenomys (Rodentia: Hystricognathi) and nematodes of the genus Paraspidodera (Heterakoidea: Aspidoderidae) in the Neotropics: temporal and evolutionary implications. Zoological Journal of the Linnean Society 102:169-201.

GardneR, S. L, AND D.W. Duszynski. 1990. Polymorphism of Eimerian Oocysts can be a problem in naturally infected hosts: An example from subterranean Rodents in Bolivia. Journal of Parasitology 76:805-811.

GardneR, S. L. AND L. Ruedas. 2019. Origin and development of the South American montane mammal fauna by the Andean speciation engine. Abstract 197: 81. http:// www.mammalsociety.org/uploads/2019\%20ASM\%20Abstracts-2019.06.18.pdf

GardneR, S. L. 1991. Phyletic coevolution between subterranean rodents of the genus Ctenomys (Rodentia: Hystricognathi) and nematodes of the genus Paraspidodera (Het- erakoidea: Aspidoderidae) in the Neotropics: temporal and evolutionary implications. Zoological Journal of the Linnean Society 102:169-201.

Gardner, S. L., AND S. Anderson. 2001. Persistent fontanelles in rodent skulls. American Museum Novitates 3327:1-15.

Gardner, S. L., J. Salazar-bravo, and J. A. Cook. 2014. New Species of Ctenomys Blainville 1826 (Rodentia: Ctenomyidae) from the lowlands and central valleys of Bolivia. Special Publications, Museum of Texas Tech University 62:1-34.

Hengl, T., G. B. Mendes de Jesus, M. Heuvelink, M. R. Gonzalez, M. Kilibarda, A. Blagotić, W. Shangguan, M. N. Wright, X. Geng, B. Bauer-Marschallinger, M. A. Guevara, R. Vargas, R. A. MacMillan, N. H. Batjes, J. G. B. Leenaars, E. Ribeiro, I. Wheeler, S.MAntel, AND B. Kempen. 2017. SoilGrids250m: Global gridded soil information based on machine learning. Plos One 12:e0169748.

IBisch, P., S. Beck, B. Gerkmann, and Y.A. Carretero. 2003. Ecoregiones y ecosistemas. Pp. 47-88, in Biodiversidad: La Riqueza de Bolivia (Ibisch, P., and G. Mérida, eds.). FAN. Santa Cruz, Bolivia.

IUCN. 2020. The IUCN Red List of Threatened Species. Version 20201. https://www.iucnredlist.org. Downloaded on 20 May 2020.

Lacey, E. A., J. L. Patton, and G. N. Cameron. 2000. Life underground: the biology of subterranean rodents. University of Chicago Press. Chicago, Illinois.

Lambert, C. R., S. L. Gardner, AND D. W. Duszynski. 1988. Coccidia (Apicomplexa: Eimeriidae) from the subterranean rodent Ctenomys opimus Wagner (Ctenomyidae) from Bolivia, South America. Journal of Parasitology 74:1018-1022.

LessA, E. P., AND J. A. Cook. 1998. The molecular phylogenetics of tuco-tucos (genus Ctenomys, Rodentia: Octodontidae) suggests an early burst of speciation. Molecular Phylogenetics and Evolution 9:88-99.

LóPEz, R. P. 2003. Phytogeographical relations of the Andean dry valleys of Bolivia. Journal of Biogeography 30:1659-1668.

Mascheretti, S., P. Mirol, M. Giménez, C. Bidau, J. Contreras, and J. Searle. 2000. Phylogenetics of the speciose and chromosomally variable genus Ctenomys (Ctenomyidae: Octodontoidea), based on mitochondrial cytochrome-b sequences. Biological Journal of the Linnean Society 70: 361-376.

Mcquarrie, N., B. K. Horton, G. Zandt, S. Beck, and P. G. Decelles. 2005. Lithospheric evolution of the Andean fold-thrust belt, Bolivia, and the origin of the central Andean plateau. Tectonophysics 399:15-37.

Ministerio De Medio Ambiente y Agua. 2009. Libro rojo de la fauna silvestre de vertebrados de Bolivia. Ministerio de Medio Ambiente y Agua. La Paz, Bolivia.

Muscarella, R., P. J. Galante, M. Soley-guardia, R. A. Boria, J. M. Kass, M. Uriarte, and R. P. Anderson. 2014. ENM eval: An $\mathrm{R}$ package for conducting spatially independent evaluations and estimating optimal model complexity for Maxent ecological niche models. Methods in Ecology and Evolution 5:1198-1205.

Olrog, C. C., and M. M. Lucero. 1981. Guía de los mamíferos argentinos. Ministerio de Cultura y Educación, Tucumán: Fundación Miguel Lillo.

Parada, A. S., G. D'Elía, C. J. Bidau, and E. P. Lessa. 2011. Species groups and the evolutionary diversification of tuco-tucos, genus Ctenomys (Rodentia: Ctenomyidae). Journal of Mammalogy 92:671-682. 
Pearson, O. P. 1959. Biology of the subterranean rodents, Ctenomys, in Peru. Memorias del Museo de Historia Natural Javier Prado 9:3-56.

Phillips, S. J., AND M. Dudík. 2008. Modeling of species distributions with Maxent: new extensions and a comprehensive evaluation. Ecography 31:161-175.

Pucu, E., M. Lareschi, and S. L. Gardner. 2014. Bolivian ectoparasites: a survey of the fleas of Ctenomys (Rodentia: Ctenomyidae). Comparative Parasitology 81:114-118.

Raxworthy, C. J., E. Martinez-meyer, N. Horning, R. A. Nussbaum, G. E. Schneider, M. A. Ortega-huerta, and A. T. Peterson. 2003. Predicting distributions of known and unknown reptile species in Madagascar. Nature 426:837-841.

Ridgway, R. 1912. Color standards and color nomenclature. Published by the author, A. Hoen (printer). Baltimore, Maryland. 53 colored plates.

Roach, N., AND L. Naylor. 2016a. Ctenomys lewisi. The IUCN Red List of Threatened Species 2016: e.T5811A22193810. https:// dx.doi.org/10.2305/IUCN.UK.2016-2.RLTS.T5811A22193810. en. Downloaded on 06 June 2020.

Roach, N., and L. Naylor. 2016b. Ctenomys steinbachi. The IUCN Red List of Threatened Species 2016: e.T5827A22194994. https://dx.doi.org/10.2305/IUCN.UK.2016-2.RLTS. T5827A22194994.en. Downloaded on 12 June 2020.

Teta, P., AND G. D'ElíA. 2020. Uncovering the species diversity of subterranean rodents at the end of the World: Three new species of Patagonian tuco-tucos (Rodentia, Hystricomorpha, Ctenomys). PeerJ. 2020;8:e9259. Published 2020 May 29. doi:10.7717/peerj.9259

Tномаs, O. 1919. Two new rodents from Tartagal, Salta, N. Argentina. Annals and Magazine of Natural History, ser. 9, 4: 154-156.

Tномаs, 0. 1921. A new tuco-tuco from Bolivia. Annals and Magazine of Natural History, ser. 9, 7:136-137.

Tномаs, O. 1926. The Spedan Lewis South American exploration, II: On mammals collected in the Tarija Department, southern Bolivia. Annals and Magazine of Natural History, ser. 9, 17:318-328.

Unzueta, Q. O. 1975. Mapa ecológico de Bolivia. 1:1,000,000. Ministerio de Asuntos Campesinos y Agropecuarios, Memoria explicativa by Unzueta, 11 pp. Color pl., 312 pp.

VIvar, E. 2017. Ctenomys frater (errata version published in 2018). The IUCN Red List of Threatened Species 2017: e.T115553730A123796865. https://dx.doi.org/10.2305/IUCN. UK.2017-3.RLTS.T115553730A115553734.en. Downloaded on 04 June 2020.

Wallace, A. R. 1876. The geographical distribution of animals. With a study of the relations of living and extinct faunas as elucidating the past changes of the earth's surface. Volumes 1 and 2. Macmillan and Co. London, U.K.

Wilson, D. E., ANd D. M. Reeder (eds.). 2005. Mammal Species of the World, a Taxonomic and Geographic Reference, 3rd ed. Johns Hopkins Press, Baltimore, Maryland.

Wilson, D. E., T. E. Lacher JR., And R. A. Mittermeier (eds.). 2017. The Mammals of the World-Vol. 7, Rodents II. Lynx Edicions. Barcelona, España.

Zeballos, H., AND E. Vivar . 2016. Ctenomys leucodon. The IUCN Red List of Threatened Species 2016: e.T5810A22193526. https://dx.doi.org/10.2305/IUCN.UK.2016-2.RLTS. T5810A22193526.en. Downloaded on 05 June 2020.
Zurell, D., J. Franklin, C. König, P. J. Bouchet, C. F. Dormann, J. Elith, G. Fandos, X. Feng, G. Guillera-Arroita, A. Guisan, and J. J. Lahoz-Monfort. 2020. A standard protocol for reporting species distribution models. Ecography 43:1261-1277.

Associated editor: Guillermo D'Elía

Submitted: June26, 2020; Reviewed: July 2, 2020;

Accepted: November 11, 2020; Published on line: December 23, 2020. 